\title{
PENGARUH KONSENTRASI SUKROSA DAN LAMA FERMENTASI TERHADAP KARAKTERISTIK KOMBU SALAK BONGKOK (Salacca edulis. Reinw)
}

\author{
Oleh: \\ Yopi Setiawan, S.T.,M.T.
}

\begin{abstract}
Abstrak
Tujuan dari penelitian ini adalah untuk menentukan rasio air dengan buah-buahan yang sesuai dan untuk menentukan konsentrasi stabilizer yang tepat dan untuk menyelidiki interaksi antara rasio buah dengan air dan konsentrasi stabilizer pada karakteristik jus buah salak Bongkok.

Penelitian pendahuluan adalah untuk menentukan penambahan konsentrasi sukrosa dan zat penstabil yang tepat dengan respons organoleptik. Penelitian utama dilakukan dengan menggunakan Rancangan Acak Kelompok (RAK) yang terdiri dari dua faktor: faktor A (perbandingan buah dengan air), yang terdiri dari 5 level yaitu a1 (1: 1), a2 (1: 2), a3 (1) : 3), a4 (1: 4), a5 (1: 5) dan faktor B (konsentrasi stabilizer), yang terdiri dari tiga level yaitu b1 $(0,5 \%)$, b2 (0,75\%), b3 (1\%). Respon yang digunakan dalam studi utama adalah respon kimia yang terdiri dari aktivitas antioksidan, kadar air dan TSS (Total Soluble Solid), respon fisik yang viskositas dan respon organoleptik yang meliputi rasa, aroma dan penampilan.

Berdasarkan hasil penelitian pendahuluan, diperoleh konsentrasi sukrosa terbaik 10\% dan jenis stabilisator terbaik yaitu dekstrin (perlakuan a3b2 dengan kode sampel 896). Berdasarkan hasil penelitian primer, diketahui bahwa perbandingan interaksi buah dengan air dan konsentrasi zat penstabil berpengaruh signifikan terhadap aktivitas antioksidan, kadar air, TSS dan viskositas.

Perlakuan terbaik adalah jus buah dan air dengan perbandingan 1: 1 dengan konsentrasi stabilizer 0,5\% (perlakuan a1b1 dengan kode sampel 392) yang memiliki nilai IC50 $91.9555 \mathrm{mg} / \mathrm{mL}$, kadar air 69,725\%, sebesar 26,185\% TSS dan viskositas 2,8885 kg / ms.
\end{abstract}

Kata Kunci : Salak bongkok, Kombu salak.

\begin{abstract}
The aim of this study was to determine the ratio of water with fruits appropriate and to determine the appropriate concentration of stabilizer and to investigate the interaction between the ratio of the fruit with water and the concentration of the stabilizer on the characteristics of the juice of snakefruits Bongkok.

The preliminary study is to determine the appropriate addition of sucrose concentration and stabilizer right with organoleptic response. Primary research carried out by using a randomized block design (RBD) consisting of two factors: factor $A$ (comparison fruit with water), which consists of 5 levels ie $a_{1}$ (1: 1), $a_{2}$ (1: 2), a3 (1:3), a4 (1:4), a5 (1:5) and factor B (concentration of stabilizer), which consists of three levels ie $b_{1}(0.5 \%), b_{2}(0.75 \%), b_{3}(1 \%)$. The responses are used in the main study chemical response that consists of antioxidant activity, moisture content and TSS (Total Soluble Solid), physical responses that the viscosity and organoleptic responses that include taste, aroma and appearance.

Based on preliminary research results, obtained the best sucrose concentrations of $10 \%$ and the best type of stabilizer that is dextrin (a $b_{2}$ treatment with sample code 896). Based on the results of primary research, it is known that the interaction comparisons fruit with water and concentration of stabilizer significant effect on antioxidant activity, moisture content, TSS and viscosity.
\end{abstract}


The best treatment is fruit juice and water with a ratio of 1: 1 with a stabilizer concentration of 0.5\% (a1 $b_{1}$ treatment with sample code 392) which has a value of $I_{50} 91.9555 \mathrm{mg} / \mathrm{mL}$, the water content of $69.725 \%$, amounting to $26.185 \%$ TSS and viscosity of $2.8885 \mathrm{~kg} / \mathrm{m.s}$.

Keywords: Salak bongkok, Kombu salak. 


\section{PENDAHULUAN}

Tanaman salak (Salacca edulis, Reinw) merupakan salah satu tanaman buah tropis asli Indonesia. Hal ini tercermin dari ragam varietas salak yang dapat dijumpai di hampir semua propinsi di wilayah nusantara. Menurut Puslitbang Hortikultura kersikan dari Indonesia memperoleh penghargaan dengan sebutan "Great Tropical Fruits". Potensi plasma nutfah tanaman salak di Indonesia makin beragam dan bertambah terus jumlah varietas dan kultivarnya dengan adanya pengembangan budi daya di berbagai daerah (Rukmana, 1999).

Kabupaten Sumedang merupakan salah satu daerah produksi Propinsi Jawa Barat yang mengembangkan usaha hortikultura buah-buahan khususnya salak. Salak lokal yang dikembangkan di Kabupaten Sumedang adalah salak Bongkok yang pertama kali ditemukan di Desa Bongkok, Kecamatan Conggeang, Kabupaten Sumedang Jawa Barat (Dinas Pertanian Kabupaten Sumedang, 2002).

Berdasarkan data statistik produksi salak Bongkok dari tahun 2008-2012 dapat diketahui bahwa produktivitas salak Bongkok pada tahun 2008 yaitu 203.390 kwintal, tahun 2009 yaitu 159.632 kwintal, tahun 2010 yaitu 35.918 kwintal dan pada tahun 2012 yaitu 48.887 kw. Pada tahun 2008 sampai tahun 2009, jumlah produksi buah salak Bongkok di Kabupaten Sumedang megalami penurunan produktivitas, sedangkan pada tahun 2009 sampai tahun 2012 jumlah produksi salak Bongkok di Kabupaten Sumedang kembali mengalami kenaikan produktivitas (Badan Pusat Statistik Jawa Barat, 2008-2012).

Beberapa penelitian menjelaskan bahwa buah salak Bongkok mengandung vitamin C 8,37 mg/100g dan selain itu terdapat suatu senyawa 2 -metilester-1-Hpirrol-4-asam karboksilat yang mempunyai aktivitas sebagai antioksidan dengan inhibitor dari DPPH (2,2 Diphenyl1, picrylhydrazid) adalah 90,60\% (2000 $\mathrm{mg} / \mathrm{mL}$ ) $\mathrm{IC} 50 \%=33,92 \mathrm{mg} / \mathrm{mL}$. Asam askorbat (sebagai referensi) substansi adalah 95,56\% IC50\% $=3,18 \mathrm{mg} / \mathrm{mL}$. Hasil penapisan fitokimia terhadap simplisia buah salak Bongkok menunjukan adanya flavonoid, alkaloid, terpenoid, tannin katekat dan kuinon, sedangkan saponin tidak ditemukan (Afrianti, et al., 2010). Selain itu buah salak varietas Bongkok ini dapat menurunkan produksi asam urat secara in vivo dan in vitro (Afrianti et al., 2011).

Kandungan vitamin C sebagai antioksidan yang tinggi, flavonoid, alkaloid, terpenoid, tannin katekat, kuinon dan menurunkan produksi asam urat pada salak varietas Bongkok ini bermanfaat untuk kesehatan manusia, oleh karena itu salak varietas Bongkok ini berpotensi dapat dimanfaatkan menjadi suatu produk fungsional (Afrianti dkk, 2007).

Buah salak Bongkok memiliki rasa yang asam, sepat dan agak pahit sehingga buah salak Bongkok tidak diminati oleh konsumen yang mengakibatkan buah salak Bongkok menjadi komoditi yang terbuang (Permatasari, 2012). Selain itu, buah salak mudah rusak akibat faktor mekanis, fisis, mikrobiologis dan fisiologis. Pengolahan minuman sari buah salak varietas Bongkok merupakan salah satu cara untuk memanfaatkan buah agar tidak terbuang. Selain itu, pengolahan ini dapat memperpanjang umur simpan buah salak serta untuk menambah diversifikasi produk pangan.

Menurut Standar Nasional Indonesia (1995), minuman sari buah adalah minuman ringan yang dibuat dari buah dan air dengan atau tanpa penambahan gula dan bahan tambahan makanan yang diizinkan. Menurut Fauzan (2010), minuman sari buah secara komersial dikenal dengan nama juice dibuat dengan cara ekstraksi buah ditambah dengan air dan gula sebanyak \pm $5-10 \%$.

Perbandingan air dengan ekstrak memiliki pengaruh terhadap warna, rasa, dan aroma. Semakin besar perbandingan 
air yang ditambahkan maka warna akan semakin terang hingga pucat, aromanya kurang khas, rasa akan semakin hambar dan kekentalannya pun rendah, begitupun sebaliknya (Gustianova, 2012).

Masalah yang sering dihadapi dalam pembuatan sari buah adalah kerusakan suspensi dari sari buah. Kerusakan suspensi sari buah dapat berupa endapan serta perubahan warna dan rupa yang tidak diinginkan, untuk mengatasi masalah ini, perlu ditambahkan bahan penstabil dengan tujuan untuk mendapatkan kestabilan sari buah yang dianjurkan yaitu minimal 50\% (SNI, 1995).

Beberapa jenis bahan penstabil yang digunakan dalam pembuatan sari buah umumnya adalah CMC, gum arab dan dekstrin. Namun, penamabahan bahan penstabil umumnya berpengaruh terhadap viskositas larutan.

Penambahan konsentrasi CMC yang berlebihan dapat meningkatkan viskositas larutan. (Kamal, 2010). Selain itu, dengan menambahakan gum arab pada larutan, viskositas akan meningkat sebanding dengan peningkatan konsentrasi (Tranggono dkk, 1991).

Berdasarkan uraian diatas maka perlu dilakukan penelitian untuk mengetahui pengaruh perbandingan air dengan sari buah dan konsentrasi penstabil terhadap karakteristik minuman sari buah.

Berdasarkan latar belakang penelitian diatas, masalah yang dapat diidentifikasikan adalah sebagai berikut:

1. Apakah variasi perbandingan buah salak dengan air berpengaruh terhadap karakteristik sari buah salak varietas Bongkok.

2. Apakah konsentrasi penstabil berpengaruh terhadap karakteristik minuman sari buah salak varietas Bongkok (Salacca edulis Reinw).

3. Apakah interaksi perbandingan buah salak dengan air dan konsentrasi penstabil berpengaruh terhadap karakteristik minuman sari buah salak varietas Bongkok (Salacca edulis Reinw).
Maksud dari penelitian ini adalah untuk mengetahui bagaimana pengaruh perbandingan buah salak dengan air dan pengaruh konsentrasi penstabil serta interaksi perbandingan buah salak dengan air dan konsentrasi penstabil terhadap karakteristik minuman sari buah salak Bongkok.

Tujuan dari penelitian ini adalah untuk menentukan perbandingan air dengan buah salak yang tepat dan untuk menentukan konsentrasi penstabil yang tepat sehingga akan diperoleh minuman sari buah salak yang mempunyai karakteristik baik dan dapat diterima oleh konsumen.

Manfaat yang ingin dicapai dari pembuatan minuman sari buah salak varietas Bongkok adalah meningkatkan nilai ekonomis dari daging salak varietas Bongkok, meningkatkan nilai jual buah salak varietas Bongkok, menambah variasi produk yang berbahan baku salak dan sebagai salah satu produk diversifikasi minuman serta memberikan informasi tentang cara mengawetkan buah salak.

\section{Kerangka Pemikiran}

Sari buah adalah cairan yang dihasilkan dari penghancuran buah segar yang matang. Pada prinsipnya dikenal dua macam sari buah, yaitu sari buah encer yang diperoleh dari pengepresan daging buah, dilanjutkan dengan penambahan air, penambahan atau tanpa penambahan gula dan sari buah pekat yaitu cairan yang dihasilkan dari pengepresan daging buah dan dilanjutkan dengan proses pemekatan (Triyono, 2010).

Menurut Farikha dkk (2013), tahapan pembuatan sari buah, meliputi sortasi buah, pencucian, pengupasan, pemotongan, penghancuran daging buah, filtrasi, homogenisasi, pasteurisasi, pengemasan, dan penyimpanan.

Sedangkan menurut Gustianova (2012), proses pembuatan sari buah pada prinsipnya terdiri dari tahapan ekstraksi, penyaringan, pemanasan, dan pengemasan. Dalam pembuatan sari buah tertentu misalnya salak, proses ekstraksi 
untuk mendapatkan cairan buah dapat dilakukan dengan pengepresan (menggunakan juice extractor atau juice presser), penghancuran (dengan blender atau parutan), atau dengan cara perebusan atau dengan mengekstraksinya dengan menggunakan pelarut.

Buah yang digunakan untuk membuat sari buah adalah buah yang telah matang, dalam bentuk segar atau yang dipertahankan dalam kondisi yang baik dengan peralatan. Buah tersebut dapat langsung diolah menjadi sari buah atau terlebih dahulu dibuat menjadi puree maupun konsentrat sari buah (Gustianova, 2012).

Menurut Farikha dkk (2013), masalah yang timbul pada minuman sari buah naga adalah timbulnya endapan selama penyimpanan. Dalam pembuatan minuman sari buah keruh diperlukan bahan penstabil untuk mempertahankan kondisi keruh dan mencegah pengendapan. Pada penelitian ini digunakan 3 jenis bahan penstabil, yaitu CMC (Carboxyl Metbyl Cellulose), gum arab dan dekstrin.

Penggunaan CMC (Carboxyl Metbyl (Cellulose) dapat digunakan sebagai stabilizier pada pembuatan minuman madu sari buah jambu merah. CMC (Carboxyl Methyl Cellulose) berfungsi mempertahankan kestabilan minuman agar partikel padatannya tetap terdispersi merata ke seluruh bagian sehingga tidak mengalami pengendapan. CMC juga dapat memperbaiki citarasa, warna, dan konsistensi sari buah (Kamal, 2010).

Menurut Siskawardani dkk (2013), penambahan CMC sebanyak $0,04 \%$ merupakan perlakuan terbaik pada pembuatan minuman asam sari tebu. Sedangkan menurut Prasetyo dkk (2014), penambahan CMC sebanyak 0,05\% dapat meningkatkan viskositas dan mutu organoleptik pada minuman madu sari buah jambu merah.

Penambahan bahan penstabil CMC dengan konsentrasi $2 \%$ merupakan perlakuan terbaik pada pembuatan sari buah nangka (Fauzan, 2010). Menurut
Manoi (2006) Penggunaan CMC lebih efektif dibandingkan dengan gum arab atau gelatin. Penambahan CMC dengan konsentrasi $0,5-3 \%$ sering digunakan untuk mempertahankan kestabilan suspensi. Perlakuan penambahan bahan CMC (Carboxyl Methyl Cellulose) 1,5\% memberikan hasil terbaik pada pembuatan sirup jambu mete.

Gum arab dapat digunakan sebagai penstabil dengan maksimal penggunaan 0,05\% (Saptoningsih, 2012). Konsentrasi penambahan gum arab sebanyak $0,1 \%$ menghasilkan minuman madu sari buah jambu merah yang berkualitas baik (Gitawuri, 2014).

Menurut Suzanty (2009), hasil uji organoleptik sari kedelai instan menunjukkan bahwa sampel dengan bahan penstabil dekstrin $0,2 \%$ merupakan sampel terbaik. Menurut Amalia (2011), hasil penelitian pembuatan sirup buah kawis didapatkan nilai kekeruhan terendah pada penambahan dekstrin dengan massa 7,5 gram/L.

Selain masalah terbentuknya endapan, salak dapat mengalami perubahan warna akibat aktivitas enzim yang terkandung di dalam buah salak. Oleh karena itu, salak harus melewati perlakuan blanching untuk menginaktifkan enzim yang dapat merusak suspensi sari buah salak sehingga terbentuk endapan pada produk minuman, disamping itu blanching juga dapat mengurangi jumlah populasi mikroorganisme pada bahan pangan tersebut.

Menurut Aminah dkk (2008), dalam pembuatan sari buah belimbing, dilakukan blanching pada air panas $\left(80^{\circ} \mathrm{C}\right)$ selama 3 menit untuk mencegah terjadinya pencoklatan pada buah belimbing.

Menurut Sa'adah dkk (2015), minuman sari buah adalah sari buah yang telah diencerkan dengan menggunakan air. Kandungan sari buah pada minuman minimal harus 35\% dengan atau tanpa penambahan gula.

Menurut penelitian Suhartini (2002), penambahan air pada pembuatan 
sari buah lidah buaya didapat hasil terbaik 1:2. Menurut Widyasari (2007), perbandingan air yang paling disukai pada penelitiannya yaitu dalam pembuatan sari buah jambu mete adalah 1 : 3. Menurut Gustianova (2012), perbandingan air yang paling disukai pada penelitiannya yaitu dalam pembuatan minuman ekstrak buah salak Bongkok adalah 1 : 4.

Menurut Sa'adah dkk (2015), jumlah gula yang ditambabkan adalah sebanyak 100 gram atau lebih untuk setiap liternya, tergantung dari tingkat kemanisan buah yang digunakan dan tingkat kemanisan minuman sari buah yang dikehendaki. Menurut Fauzan (2010), penambahan gula sebanyak 15\% pada pembuatan sari buah nangka merupakan sari buah yang paling disukai oleh panelis.

Produk sari buah yang mempunyai tingkat keasaman tinggi (nilai $\mathrm{pH} 4,5-5)$ dapat dipasteurisasi pada suhu antara $160-165^{\circ} \mathrm{F}$ atau $71,1-73,9^{\circ} \mathrm{C}$ (Farikha dkk, 2013). Menurut Ariyanto (2013), untuk menghilangkan mikroba pada sari buah apel, dilakukan proses pasteurisasi pada suhu $70^{\circ} \mathrm{C}$ selama 20 menit. Sedangkan menurut Pertiwi (2014), proses pasteurisasi pada produk sari stroberi dilakukan pada suhu $65^{\circ} \mathrm{C}$ selama 15 menit.

\section{Hipotesa Penelitian}

Berdasarkan kerangka pemikiran diatas, maka dapat diambil hipotesis diduga bahwa :

1. Variasi perbandingan air dengan buah salak berpengaruh terhadap karakteristik minuman sari buah salak varietas Bongkok (Salacca edulis Reinw).

2. Konsentrasi penstabil berpengaruh terhadap karakteristik minuman sari buah salak varietas Bongkok (Salacca edulis Reinw).

3. Interaksi perbandingan air dengan buah salakdan konsentrasi bahan penstabil berpengaruh terhadap karakterisitk minuman sari buah salak Bongkok.

\section{METODE PENELITIAN}

\section{Waktu dan Tempat}

Penelitian akan dilakukan dan dimulai pada bulan Juni sampai dengan Oktober 2015, bertempat di Laboratoium Penelitian Jurusan Teknologi Pangan, Fakultas Teknik, Universitas Pasundan, Bandung.

\section{Bahan}

Bahan yang digunakan untuk pembuatan minuman sari buah salak diantaranya adalah salak varietas Bongkok yang diperoleh dari desa Bongkok, kecamatan Conggeang, Sumedang, Jawa Barat, air, gula pasir, Carboxyl Metbyl Cellulose, gum arab dan dekstrin. Bahan yang digunakan untuk analisis adalah reagen DPPH, toluen, alkohol, metanol dan aquadest.

\section{Alat}

Alat-alat yang digunakan dalam penelitian ini adalah blender, panci, kompor gas, kain blacu dan lemari pendingin. Alat yang digunakan untuk analisis adalah spektrofotometri, pipet, gelas kimia, labu erlenmeyer, kertas saring, tabung reaksi, timbangan digital, pipet mikro, pipet volumetri, piknometer, labu destilasi, labu takar $25 \mathrm{~mL}$, eksikator, oven dan viskometer ostwald.

\section{Metode Penelitian}

Metode penelitian yang dilakukan meliputi: rancangan perlakuan, rancangan percobaan, rancangan respon, dan prosedur penelitian.

\section{Rancangan Perlakuan}

Rancangan Perlakuan terdiri dari penelitian pendahuluan dan penelitian utama.

\section{Penelitian Pendahuluan}

Perlakuan yang digunakan pada penelitian pendahuluan adalah menentukan penambahan konsentrasi sukrosa dan jenis penstabil yang tepat. 
Konsentrasi sukrosa yang ditambahkan yaitu 5, 10 dan 15\% sedangkan jenis bahan penstabil yang digunakan yaitu Carboxyl Metbyl Cellulose, gum arab dan dekstrin.

\section{Penelitian Utama}

Rancangan percobaan yang digunakan dalam penelitian utama ini adalah Rancangan Acak Kelompok (RAK) dengan pola faktorial (5x3) dengan 2 (dua) kali ulangan
1. Faktor perbandingan buah dengan air (A) terdiri dari 5 taraf, yaitu 1:1, 1:2, 1:3, 1:4 dan 1:5.

2. Faktor konsentrasi penstabil (B) terdiri dari 3 taraf, yaitu $0,5 \%, 0,75 \%$ dan $1 \%$.

\section{Rancangan Percobaan}

Rancangan percobaan yang digunakan dalam penelitian utama adalah Rancangan Acak Kelompok (RAK) dengan pola faktorial (5x3) dengan 2 kali ulangan, sehingga didapatkan 30perlakuan seperti yang terlihat pada Tabel 1 .

Tabel 1. Model Percobaan Rancangan Acak Kelompok Pola Faktorial 5x3 dengan 2 Kali Ulangan

\begin{tabular}{|c|c|c|c|}
\hline \multirow{2}{*}{$\begin{array}{c}\text { Perbandingan } \\
\text { Buah dengan Air } \\
\text { (A) }\end{array}$} & $\begin{array}{c}\text { Konsentrasi Bahan } \\
\text { Penstabil (B) }\end{array}$ & Ulangan \\
\cline { 3 - 4 } & & $\mathrm{I}_{1}$ & II \\
\hline \multirow{2}{*}{$\mathrm{a}_{1}$} & $\mathrm{~b}_{1}$ & $\mathrm{a}_{1} \mathrm{~b}_{1}$ & $\mathrm{a}_{1} \mathrm{~b}_{1}$ \\
& $\mathrm{~b}_{2}$ & $\mathrm{a}_{1} \mathrm{~b}_{2}$ & $\mathrm{a}_{1} \mathrm{~b}_{2}$ \\
& $\mathrm{~b}_{3}$ & $\mathrm{a}_{1} \mathrm{~b}_{3}$ & $\mathrm{a}_{1} \mathrm{~b}_{3}$ \\
\hline \multirow{2}{*}{$\mathrm{a}_{2}$} & $\mathrm{~b}_{1}$ & $\mathrm{a}_{2} \mathrm{~b}_{1}$ & $\mathrm{a}_{2} \mathrm{~b}_{1}$ \\
& $\mathrm{~b}_{2}$ & $\mathrm{a}_{2} \mathrm{~b}_{2}$ & $\mathrm{a}_{2} \mathrm{~b}_{2}$ \\
& $\mathrm{~b}_{3}$ & $\mathrm{a}_{2} \mathrm{~b}_{3}$ & $\mathrm{a}_{2} \mathrm{~b}_{3}$ \\
\hline \multirow{3}{*}{$\mathrm{a}_{3}$} & $\mathrm{~b}_{1}$ & $\mathrm{a}_{3} \mathrm{~b}_{1}$ & $\mathrm{a}_{3} \mathrm{~b}_{1}$ \\
& $\mathrm{~b}_{2}$ & $\mathrm{a}_{3} \mathrm{~b}_{2}$ & $\mathrm{a}_{3} \mathrm{~b}_{2}$ \\
& $\mathrm{~b}_{3}$ & $\mathrm{a}_{3} \mathrm{~b}_{3}$ & $\mathrm{a}_{3} \mathrm{~b}_{3}$ \\
\hline \multirow{2}{*}{$\mathrm{a}_{4}$} & $\mathrm{~b}_{1}$ & $\mathrm{a}_{4} \mathrm{~b}_{1}$ & $\mathrm{a}_{4} \mathrm{~b}_{1}$ \\
& $\mathrm{~b}_{2}$ & $\mathrm{a}_{4} \mathrm{~b}_{2}$ & $\mathrm{a}_{4} \mathrm{~b}_{2}$ \\
& $\mathrm{~b}_{3}$ & $\mathrm{a}_{4} \mathrm{~b}_{3}$ & $\mathrm{a}_{4} \mathrm{~b}_{3}$ \\
\hline \multirow{2}{*}{$\mathrm{a}_{5}$} & $\mathrm{~b}_{1}$ & $\mathrm{a}_{5} \mathrm{~b}_{1}$ & $\mathrm{a}_{5} \mathrm{~b}_{1}$ \\
& $\mathrm{~b}_{2}$ & $\mathrm{a}_{5} \mathrm{~b}_{2}$ & $\mathrm{a}_{5} \mathrm{~b}_{2}$ \\
\hline & $\mathrm{b}_{3}$ & $\mathrm{a}_{5} \mathrm{~b}_{3}$ & $\mathrm{a}_{5} \mathrm{~b}_{3}$ \\
\hline
\end{tabular}

Denah rancangan faktorial $5 \times 3$ dalam Rancangan Acak Kelompok (RAK) dengan 2 kali ulangan sebagai berikut:

Kelompok Ulangan 1

\begin{tabular}{|l|l|l|l|l|l|l|l|}
$\mathrm{a}_{3} \mathrm{~b}_{1}$ & $\mathrm{a}_{1} \mathrm{~b}_{2}$ & $\mathrm{a}_{2} \mathrm{~b}_{3}$ & $\mathrm{a}_{4} \mathrm{~b}_{2}$ & $\mathrm{a}_{4} \mathrm{~b}_{3}$ & $\mathrm{a}_{3} \mathrm{~b}_{2}$ & $\mathrm{a}_{2} \mathrm{~b}_{1}$ & $\mathrm{a}_{3} \mathrm{~b}_{3}$ \\
\hline
\end{tabular}

\begin{tabular}{|l|l|l|l|l|l|l|}
\hline $\mathrm{a}_{1} \mathrm{~b}_{1}$ & $\mathrm{a}_{2} \mathrm{~b}_{2}$ & $\mathrm{a}_{5} \mathrm{~b}_{3}$ & $\mathrm{a}_{5} \mathrm{~b}_{2}$ & $\mathrm{a}_{5} \mathrm{~b}_{1}$ & $\mathrm{a}_{1} \mathrm{~b}_{3}$ & $\mathrm{a}_{4} \mathrm{~b}_{1}$ \\
\hline
\end{tabular}

Kelompok Ulangan 2

\begin{tabular}{|l|l|l|l|l|l|l|l|}
\hline$a_{4} b_{1}$ & $a_{2} b_{3}$ & $a_{5} b_{3}$ & $a_{3} b_{2}$ & $a_{3} b_{1}$ & $a_{1} b_{1}$ & $a_{4} b_{2}$ & $a_{5} b_{1}$ \\
\hline
\end{tabular}

\begin{tabular}{|l|l|l|l|l|l|l|}
\hline$a_{1} b_{2}$ & $a_{3} b_{3}$ & $a_{1} b_{2}$ & $a_{3} b_{3}$ & $a_{1} b_{2}$ & $a_{3} b_{3}$ & $a_{1} b_{2}$ \\
\hline
\end{tabular}


Tabel 2. Analisis Variasi (ANAVA)

\begin{tabular}{|c|c|c|c|c|c|}
\hline $\begin{array}{l}\text { Sumber } \\
\text { Varians }\end{array}$ & $\begin{array}{l}\text { Derajat Bebas } \\
\text { (db) }\end{array}$ & $\begin{array}{c}\text { Jumlah Kuadrat } \\
\text { (JK) }\end{array}$ & $\begin{array}{c}\text { Kuadrat Tengah } \\
(\mathrm{KT})\end{array}$ & $F_{\text {hitung }}$ & $\begin{array}{c}\mathrm{F}_{\text {tabel }} \\
5 \%\end{array}$ \\
\hline $\begin{array}{c}\text { Kelompo } \\
\mathrm{k}\end{array}$ & $r-1$ & JKK & KTK & - & \\
\hline $\begin{array}{c}\text { Perlakuan } \\
\text { A } \\
\text { B } \\
\text { AB }\end{array}$ & $\begin{array}{c}a b-1 \\
a-1 \\
b-1 \\
(a-1)(b-1)\end{array}$ & $\begin{array}{c}- \\
\mathrm{JK}(\mathrm{A}) \\
\mathrm{JK}(\mathrm{B}) \\
\mathrm{JK}(\mathrm{AB})\end{array}$ & $\begin{array}{c}- \\
\mathrm{KT}(\mathrm{A}) \\
\mathrm{KT}(\mathrm{B}) \\
\mathrm{KT}(\mathrm{AB})\end{array}$ & $\begin{array}{c}- \\
\mathrm{KT}(\mathrm{A}) / \mathrm{KTG} \\
\mathrm{KT}(\mathrm{B}) / \mathrm{KTG} \\
\mathrm{KT}(\mathrm{AB}) / \mathrm{KT} \\
\mathrm{G}\end{array}$ & \\
\hline Galat & $(\mathrm{r}-1)(\mathrm{ab}-1)$ & $\mathrm{JKG}$ & KTG & - & \\
\hline Total & rab-1 & $\mathrm{JKT}$ & - & - & \\
\hline
\end{tabular}

Sumber : Vincent Gaspersz (1995).

Berdasarkan rancangan percobaan di atas, maka dapat ditentukan daerah penolakan hipotesis, yaitu :

1) Jika F hitung $>$ F tabel pada taraf 5\%, maka perlakuan konsentrasi dan lama perendaman dalam natrium metabisulfit, serta interaksinya berpengaruh terhadap karakteristik manisan kering salak varietas Bongkok. Dengan demikian hipotesis penelitian diterima dan dilakukan uji lanjut Duncan.

2) Jika $\mathrm{F}$ hitung $<\mathrm{F}$ tabel pada taraf 5\%, maka perlakuan konsentrasi dan lama perendaman dalam natrium metabisulfit, serta interaksinya tidak berpengaruh terhadap karakteristik manisan kering salak varietas Bongkok. Dengan demikian hipotesis penelitian ditolak.

\section{Rancangan Respon}

Rancangan respon yang akan dilakukan pada penelitian utama ini meliputi respon kimia, respon fisika dan respon organoleptik.

1) Respon Kimia

Respon kimia yang dilakukan terhadap minuman sari buah salak Bongkok ini adalah analisis aktivitas antioksidan dengan metode DPPH (Amin, 2005), kadar air dengan metode destilasi (Sudarmadji, 1967) dan uji TSS (Total Soluble Solid) metode gravimetri (Apriyantono, dkk. 1989).

\section{2) Respon Fisika}

Respon fisik yang dilakukan adalah penentuan viskositas pada minuman sari buah salak Bongkok dengan menggunakan viskometer (AOAC, 1995).

3) Respon Organoleptik

Pengujian organoleptik dilakukan terhadap rasa, aroma dan kenampakan sari buah salak Bongkok. Uji organoleptik dilakukan dengan menggunakan skala hedonik. Sampel tersebut disajikan kepada 20 orang panelis dengan kode tertentu pada setiap sampel.

\section{Deskripsi Penelitian Pendahuluan}

Deskripsi percobaan proses pembuatan minuman sari buah salak varietas Bongkok yang dilakukan dalam penelitian pendahuluan adalah sebagai berikut:

1. Penimbangan

Tahap awal yang dilakukan dalam pembuatan minuman sari buah salak yaitu penimbangan. Buah salak ditimbang sesuai dengan basis yang diperlukan.

\section{Pencucian}

Buah salak yang telah ditimbang kemudian dicuci dengan air bersih untuk menghilangkan kotoran yang menempel pada kulit salak. Pencucian dilakukan di bawah air yang mengalir.

\section{Blanching}

Proses blanching dilakukan pada suhu $80^{\circ} \mathrm{C}$ selama 7 menit. Tujuan dilakukan proses blanching adalah untuk menonaktifkan enzim sehingga produk yang dihasilkan memiliki warna yang menarik. Selain itu, proses blanching dilakukan untuk mengurangi mikroorganisme pada salak tersebut. 
4. Penirisan

Buah salak yang telah melewati proses blanching selanjutnya ditiriskan. Penirisan dilakukan untuk menghilangkan air sisa blanching.

\section{Trimming}

Proses trimming dilakukan untuk memisahkan bagian-bagian yang tidak diperlukan dalam proses. Buah salak dipisahkan dari kulit buah dengan cara mengupas kulit bagian luar buah menggunakan sarung tangan karet, kemudian bagian buah salak yang menempel dipisahkan satu persatu dan dipisahkan bijinya.

\section{Pemotongan}

Daging buah salak yang telah ditiriskan kemudian dipotong dengan menggunakan pisau. Proses pemotongan bertujuan untuk mempermudah proses penghancuran.

\section{Penghancuran}

Daging buah salak yang telah dipotong kemudian dahancurkan dengan menggunakan blender. Proses penghancuran dilakukan dengan menambahkan air dengan perbandingan antara buah dengan air yaitu 1:4.

\section{Penyaringan}

Proses selanjutnya yaitu proses penyaringan. Pada proses ini, buah salak yang telah dihancurkan disaring menggunakan kain blacu untuk mendapatkan sari buah salak yang terpisah dari ampas.

\section{Pencampuran I}

Sari buah yang telah didapat selanjutnya ditambahkan gula pasir dengan konsentrasi yang berbeda yaitu 5, 10 dan $15 \%$.

\section{Pencampuran II}

Proses pencampuran II yaitu penambahan bahan penstabil dimana bahan penstabil yang ditambahkan adalah $\mathrm{CMC}$ dengan konsentrasi $0,5 \%$, gum arab dengan konsentrasi $0,1 \%$ dan dekstrin dengan konsentrasi $0,75 \%$.

\section{Pasteurisasi}

Pasteurisasi dilakukan untuk memperpanjang umur simpan dengan cara mematikan bakteri. Pasteurisasi dilakukan pada suhu $70^{\circ} \mathrm{C}$ selama 20 menit.

Diagram alir pembuatan minuman sari buah salak Bongkok pada penelitian utama dapat dilihat pada Gambar 1.

\section{Deskripsi Penelitian Utama}

Deskripsi percobaan proses pembuatan minuman sari buah salak varietas Bongkok yang dilakukan dalam penelitian utama ini adalah sebagai berikut:

1. Penimbangan

Proses pertama yang dilakukan yaitu penimbangan. Buah salak ditimbang sesuai dengan basis yang diperlukan.

\section{Pencucian}

Buah salak yang telah ditimbang selanjutnya dicuci di bawah air yang mengalir untuk menghilangkan kotoran yang menempel pada kulit buah salak.

\section{Blanching}

Buah salak yang sudah dipisahkan dari kulit dan bijinya selanjutnya selanjutnya diblanching pada suhu $80^{\circ} \mathrm{C}$ selama 7 menit.

4. Penirisan

Buah salak yang telah melewati proses blanching selanjutnya ditiriskan. Penirisan dilakukan untuk menghilangkan air sisa blanching yang menempel pada permukaan buah salak.

\section{Trimming}

Buah salak yang sudah dicuci kemudian ditrimming untuk memisahkan bagian-bagian yang tidak diperlukan. Buah salak dipisahkan dari kulit buah dan bijinya. 
6. Pemotongan

Pemotongan buah salak dilakukan untuk mempermudah proses penghancuran.

7. Penghancuran

Proses selanjutnya yaitu penghancuran. Proses penghancuran dilakukan dengan menggunakan blender. Proses penghancuran ini dilakukan dengan penambahan air yang berbeda yaitu dengan perbandingan anatara buah dan air 1:1, 1:2, 1:3, 1:4 dan 1:5.

\section{Penyaringan}

Buah yang sudah dihancurkan selanjutnya disaring untuk dipisahkan dari ampasnya.

\section{Pencampuran I}

Sari buah yang telah didapatkan dari proses penyaringan selanjutnya ditambahkan gula pasir. Konsentrasi gula pasir yang ditambahkan sesuai dengan konsentrasi yang telah didapatkan dari hasil penelitian pendahuluan.

10. Pencampuran II

Proses pencampuran II yaitu penambahan bahan penstabil. Bahan penstabil yang ditambahkan sesuai dengan hasil penelitian pendahuluan dengan variasi konsentrasi.

\section{Pasteurisasi}

Proses selanjutnya yaitu pasteurisasi yang dilakukan pada suhu $70^{\circ} \mathrm{C}$ selama 20 menit.

Diagram alir pembuatan minuman sari buah salak Bongkok pada penelitian utama dapat dilihat pada Gambar

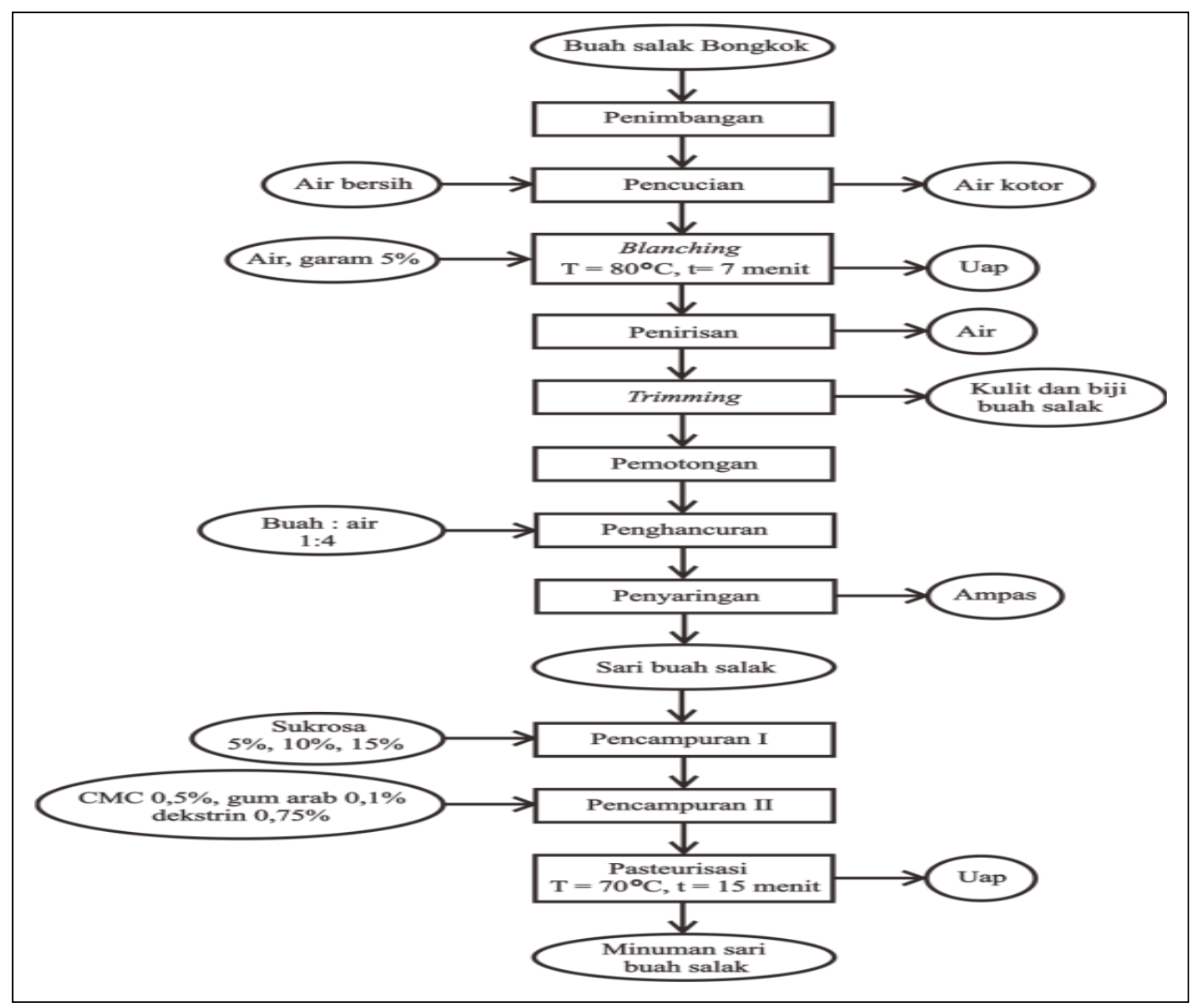

Gambar 1. Diagram Alir Penelitian Pendahuluan Pembuatan Minuman Sari Buah Salak Bongkok. 


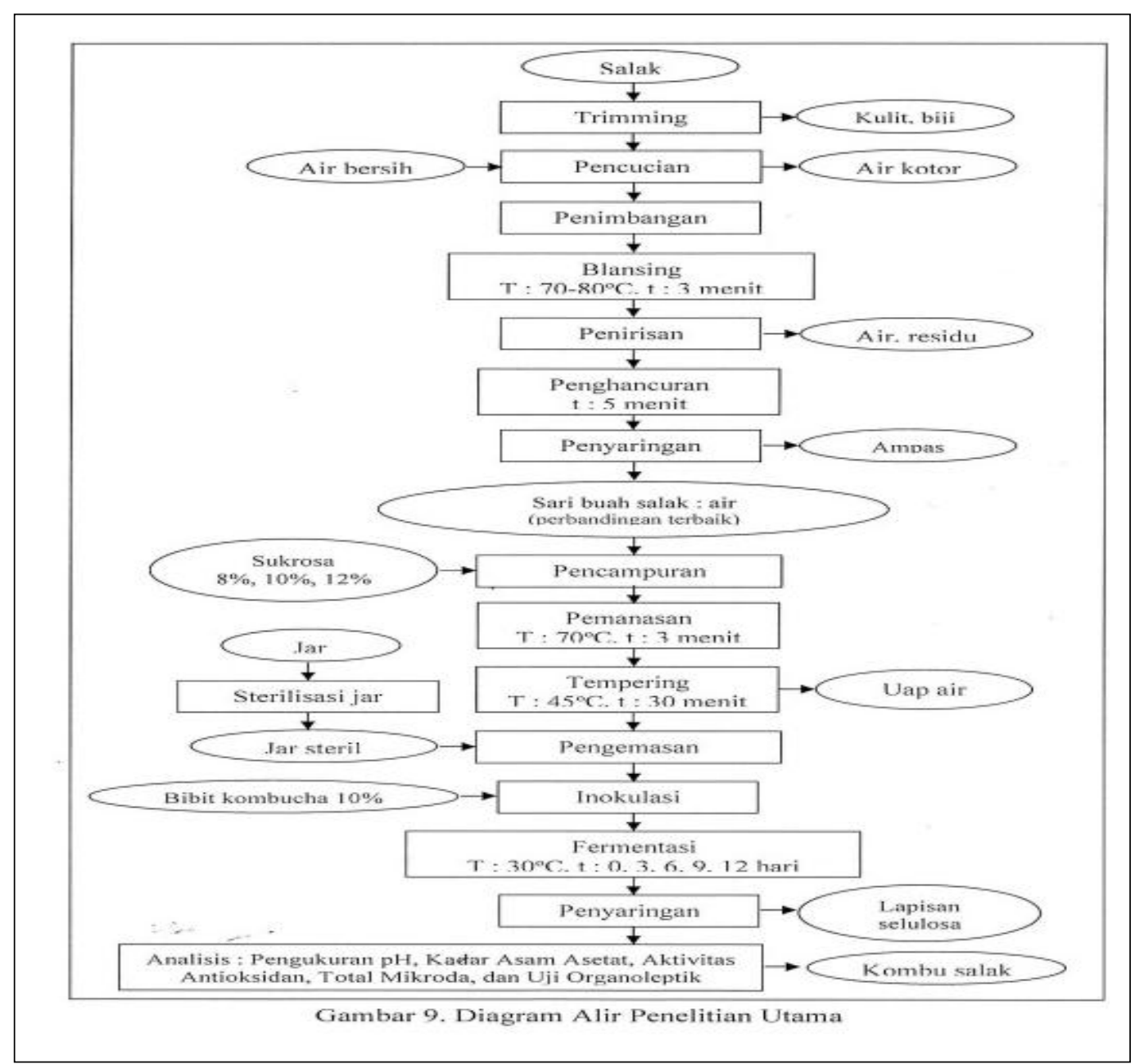

\section{HASIL DAN PEMBAHASAN}

\section{Hasil dan Pembahasan Penelitian Pendahuluan}

Penelitian pendahuluan yang dilakukan dalam pembuatan sari buah salak Bongkok, yaitu penentuan jenis bahan penstabil yang paling baik dalam pembuatan sari buah salak Bongkok dan penentuan penambahan konsentrasi sukrosa yang tepat. Penelitian pendahuluan dilakukan dengan uji organoleptik terhadap rasa, aroma dan kenampakan yang terbaik dengan menggunakan skala hedonik oleh 20 orang panelis.

Berdasarkan uji organoleptik terhadap rasa, aroma dan kenampakan terdapat perbedaan yang nyata menurut uji lanjut Duncan pada taraf 5\%. Perbedaan tersebut dapat dilihat pada Tabel 3. 
Tabel 3. Hasil Uji Organoleptik Terhadap Rasa, Aroma dan Kenampakan Sari Buah Salak Bongkok.

\begin{tabular}{|c|c|c|c|c|c|c|c|}
\hline \multirow{2}{*}{ Sampel } & \multicolumn{6}{|c|}{ Organoleptik } & \multirow{3}{*}{$\begin{array}{c}\text { Total } \\
9,3 \\
\end{array}$} \\
\hline & \multicolumn{2}{|c|}{ Rasa } & \multicolumn{2}{|c|}{ Aroma } & \multicolumn{2}{|c|}{ Kenampakan } & \\
\hline $\mathrm{a}_{1} \mathrm{~b}_{1}(\mathrm{CMC}$, sukrosa $5 \%)$ & 2,63 & $\mathrm{a}$ & 3,43 & $\mathrm{~b}$ & 3,33 & $\mathrm{a}$ & \\
\hline $\mathrm{a}_{1} \mathrm{~b}_{2}(\mathrm{CMC}$, sukrosa $10 \%)$ & 4,02 & $\mathrm{c}$ & 3,55 & $\mathrm{~b}$ & 3,45 & $\mathrm{abc}$ & 11,02 \\
\hline $\mathrm{a}_{1} \mathrm{~b}_{3}(\mathrm{CMC}$, sukrosa $15 \%)$ & 3,72 & $\mathrm{~b}$ & 3,80 & $\mathrm{c}$ & 3,37 & $\mathrm{ab}$ & 10,89 \\
\hline $\mathrm{a}_{2} \mathrm{~b}_{1}($ gum arab, sukrosa $5 \%)$ & 4,23 & $\mathrm{c}$ & 3,20 & $\mathrm{a}$ & 4,05 & $\mathrm{e}$ & 11,48 \\
\hline $\mathrm{a}_{2} \mathrm{~b}_{2}$ (gum arab, sukrosa $\left.10 \%\right)$ & 4,12 & $\mathrm{c}$ & 3,78 & $\mathrm{c}$ & 3,60 & bcd & 11,5 \\
\hline $\mathrm{a}_{2} \mathrm{~b}_{3}$ (gum arab, sukrosa $\left.15 \%\right)$ & 2,85 & $\mathrm{a}$ & 4,12 & $\mathrm{~d}$ & 3,67 & $\mathrm{~cd}$ & 10,64 \\
\hline $\mathrm{a}_{3} \mathrm{~b}_{1}$ (dekstrin, sukrosa $5 \%$ ) & 2,67 & $\mathrm{a}$ & 3,10 & $\mathrm{a}$ & 3,77 & $\mathrm{~d}$ & 9,54 \\
\hline $\mathrm{a}_{3} \mathrm{~b}_{2}$ (dekstrin, sukrosa $\left.10 \%\right)$ & 4,25 & $\mathrm{c}$ & 3,85 & $\mathrm{c}$ & 4,13 & ef & 12,23 \\
\hline $\mathrm{a}_{3} \mathrm{~b}_{3}$ (dekstrin, sukrosa $\left.15 \%\right)$ & 4,20 & $\mathrm{c}$ & 4,22 & $\mathrm{e}$ & 4,33 & $\mathrm{f}$ & 12,75 \\
\hline
\end{tabular}

Tabel 3 menunjukkan bahwa penambahan konsentrasi sukrosa yang berbeda dan penambahan jenis penstabil yang berbeda memberikan pengaruh yang nyata terhadap rasa sari buah salak Bongkok. Gitawuri (2014) menyatakan bahwa perbedaan pengaruh yang sangat nyata pada uji organoleptik (rasa) disebabkan karena ada beberapa faktor yang mempengaruhi penerimaan panelis terhadap rasa, antara lain senyawa kimia, suhu, konsentrasi, dan interaksi dengan komponen rasa yang lain. Hal tersebut dapat dilihat pada sampel dengan penambahan CMC dan dekstrin sebagai bahan penstabil memiliki rasa yang paling disukai pada penambahan sukrosa sebesar $10 \%$ yaitu pada perlakuan $\mathrm{a}_{1} \mathrm{~b}_{2}$ dan $\mathrm{a}_{3} \mathrm{~b}_{2}$ sedangkan sampel dengan penambahan gum arab sebagai penstabil yang memiliki rasa yang paling disukai pada penambahan sukrosa sebesar $5 \%$ yaitu pada perlakuan $a_{2} b_{1}$.

Penilaian panelis tehadap sari buah salak Bongkok menunjukkan bahwa panelis lebih menyukai sari buah salak Bongkok dengan penambahan sukrosa sebesar 10\%. Hal ini disebabkan sari buah salak dengan penambahan sukrosa sebesar $10 \%$ memiliki perpaduan rasa manis dan sepat khas buah salak yang pas. Sari buah salak dengan penambahan sukrosa sebesar $5 \%$, memiliki rasa yang kurang manis dan memiliki rasa khas sepat buah salak yang sangat kuat sedangkan pada sari buah salak dengan penambahan sukrosa sebesar $15 \%$ menghasilkan sari buah yang memiliki rasa sangat manis dan sudah tidak ada rasa sepat khas buah salak.

Hasil uji organoleptik pada Tabel 3 menunjukkan bahwa penambahan konsentrasi sukrosa dan jenis penstabil yang berbeda juga memberikan pengaruh yang nyata terhadap aroma sari buah salak Bongkok. Semakin tinggi konsentrasi sukrosa yang ditambahkan, semakin tinggi penilaian panelis terhadap aroma sari buah salak Bongkok. Aroma sampel dengan penambahan sukrosa 15\% lebih disukai oleh panelis yaitu pada perlakuan $\mathrm{a}_{1} \mathrm{~b}_{3}, \mathrm{a}_{2} \mathrm{~b}_{3}$ dan $\mathrm{a}_{3} \mathrm{~b}_{3}$. Hal ini dapat disebabkan karena sukrosa dapat membentuk flavor pada saat pemanasan sehingga dapat memperbaiki aroma.

Berdasarkan hasil uji organoleptik pada Tabel 3 dapat diketahui bahwa penambahan jenis penstabil yang berbeda dapat memberikan pengaruh yang nyata terhadap kenampakan sari buah salak Bongkok. Atribut mutu kenampakan yang dinilai yaitu berdasarkan endapan yang terbentuk. Hasil uji organoleptik menunjukkan bahwa panelis memberikan nilai tertinggi pada perlakuan $a_{3} b_{3}$ yang tidak berbeda nyata dengan perlakuan $a_{3} b_{2}$ dimana pada perlakuan tersebut ditambahkan dekstrin sebagai bahan penstabil sari buah salak Bongkok.

Penilaian keseluruhan sari buah salak Bongkok diihat berdasarkan penilaian panelis terhadap rasa, aroma dan kenampakan. Hal ini didukung oleh Harun (2013), yang menyatakan bahwa penilaian keseluruhan dapat dikatakan gabungan dari yang tampak seperti rasa, 
aroma dan kekentalan. Pemilihan perlakuan terpilih pada penelitian pendahuluan ditentukan berdasarkan penilaian tertinggi terhadap rasa dan kenampakan karena penelitian pendahuluan ini dilakukan untuk menentukan jumlah sukrosa yang ditambahkan ke dalam sari buah salak berdasarkan tingkat kesukaan panelis terhadap rasa sedangkan penilaian terhadap kenampakan dilakukan untuk menentukan jenis bahan penstabil yang digunakan. Berdasarkan Tabel 3 dapat disimpulkan bahwa sampel dengan perlakuan penambahan konsentrasi sukrosa sebesar $10 \%$ dan jenis bahan pestabil dekstrin merupakan perlakuan terbaik. Perlakuan tersebut selanjutnya akan digunakan untuk penelitian utama.

\section{Hasil dan Pembahasan Penelitian} Utama

Penelitian utama merupakan kelanjutan dari penelitian pendahuluan, dimana hasil uji organoleptik pada penelitian pendahuluan telah diperoleh konsentrasi sukrosa dan jenis penstabil terpilih untuk pembuatan sari buah salak Bongkok dimana konsentrasi sukrosa yang terpilih pada penelitian pendahuluan adalah sebesar $10 \%$ dan jenis bahan penstabil yang terpilih adalah dekstrin. Selanjutnya, perlakuan terpilih ini akan digunakan pada penelitian utama.

Penelitian utama dilakukan untuk mengetahui pengaruh perbandingan buah dengan air $(1: 1,1: 2,1: 3,1: 4,1: 5)$ dan konsentrasi penstabil $(0,5 \%, 0,75 \%, 1 \%)$ terhadap karakteristik sari buah salak Bongkok.

Analisis hasil penelitian utama yang dilakukan pada produk sari buah salak Bongkok adalah analisis kimia yang meliputi analisis aktivitas antioksidan, kadar air, TSS (Total Soluble Solid), analisis fisika yaitu viskositas dan uji organoleptik yang meliputi rasa, aroma dan kenampakan.

\section{Analisis Kimia \\ Antioksidan}

Uji kuantitatif daya antioksidan pada penelitian ini dilakukan dengan metode DPPH (1,1-difenil-2pikrilhidrazil) secara spektrofotometri sinar tampak. Metode ini didasarkan pada perubahan warna radikal DPPH yang disebabkan oleh reaksi antara radikal bebas DPPH dengan satu atom hidrogen yang dilepaskan senyawa yang terkandung dalam bahan uji untuk membentuk senyawa 1,1-difenil-2-pikrilhidrazin yang berwarna kuning. Pada metode ini absorbansi yang diukur adalah absorbansi larutan DPPH sisa yang tidak bereaksi dengan senyawa antioksidan (Josephy, 1997).

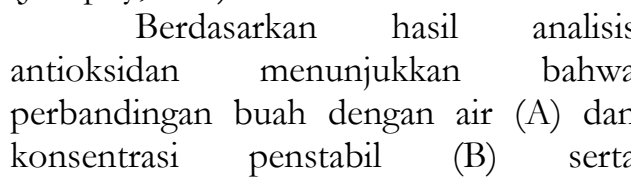
interaksinya $(\mathrm{AB})$ memberikan pengaruh nyata terhadap aktivitas antioksidan sari buah salak Bongkok. Pengaruh interaksi perbandingan buah dengan air dan konsentrasi penstabil (AB) terhadap aktivitas antioksidan sari buah salak Bongkok dapat dilihat pada Tabel 4 dan Gambar 3. 
Tabel 4. Pengaruh Interaksi Perbandingan Buah dengan Air dan Konsentrasi Penstabil (AB) Terhadap Aktivitas Antioksidan Sari Buah Salak Bongkok.

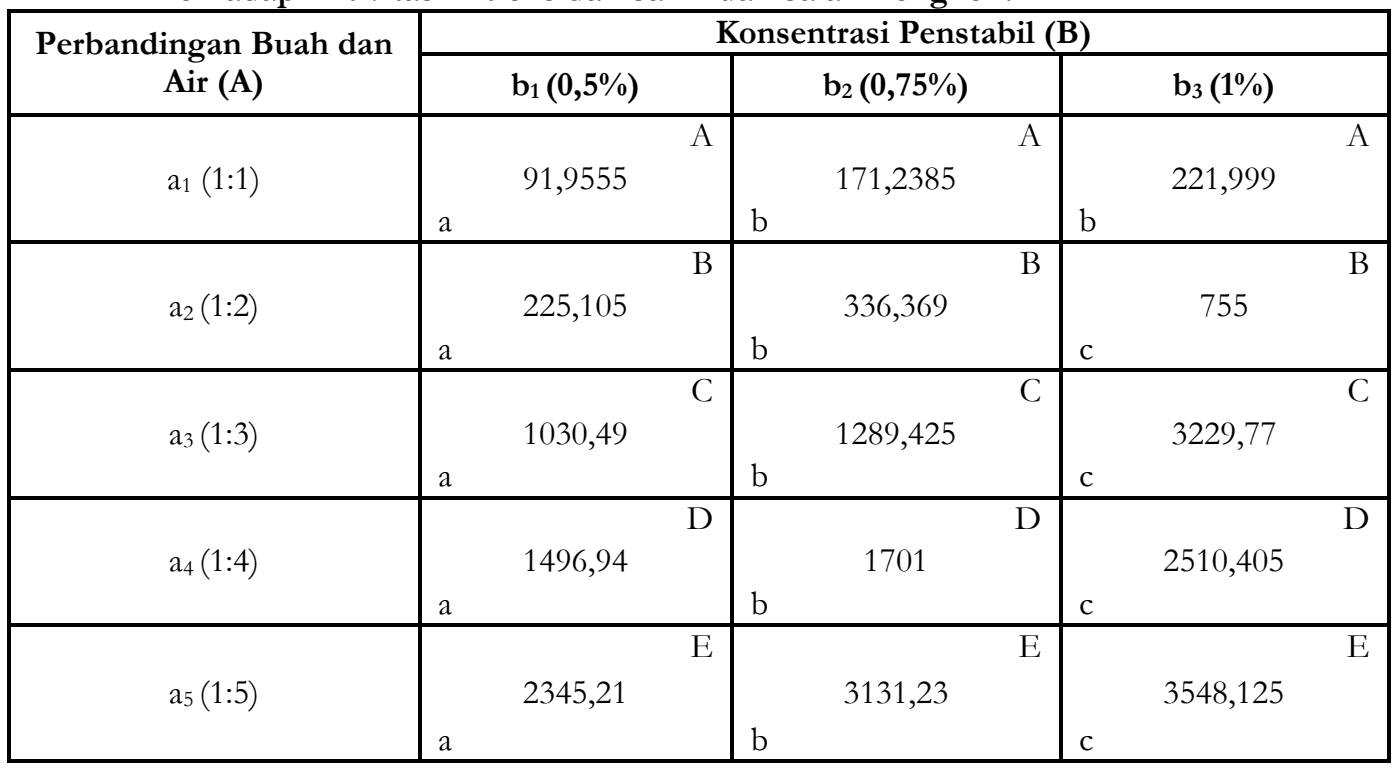

Keterangan: Setiap huruf yang berbeda menunjukkan adanya perbedaan yang nyata pada taraf 5\% Uji

Duncan (huruf kecil dibaca secara horizontal dan huruf besar secara vertikal).

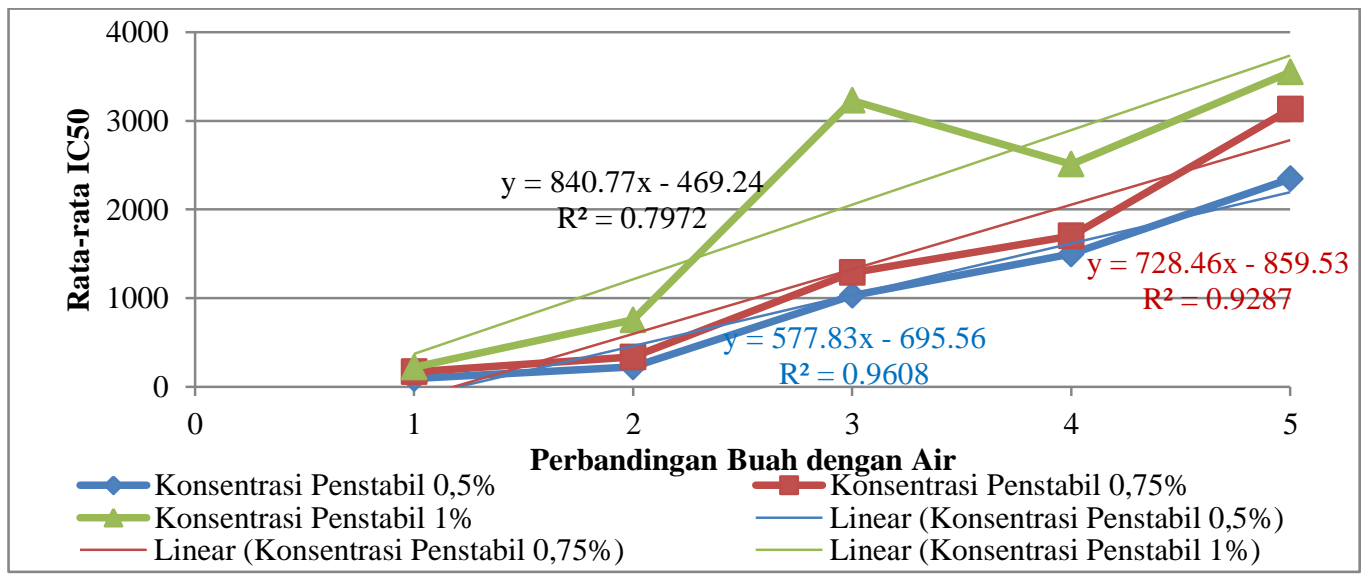

Gambar 3. Kurva Pengaruh Perbandingan Buah dengan Air Terhadap Aktivitas Antioksidan Sari Buah Salak Bongkok

Tabel 4 dan Gambar 3 menunjukkan bahwa aktivitas antioksidan tertinggi terdapat pada perlakuan $a_{1}$ yaitu pada perlakuan dengan perbandingan buah dan air 1:1. Semakin banyak jumlah penambahan air maka semakin rendah akitifas antioksidan pada sari buah salak Bongkok. Namun, hasil analisis menunjukkan bahwa sampel dengan perbandingan air yang lebih banyak mempunyai aktivitas antioksidan yang lebih tinggi seperti pada perlakuan $\mathrm{a}_{3} \mathrm{~b}_{3}$ (perbandingan buah dan air 1:3 dan konsentrasi penstabil 1\%) menunjukkan bahwa aktivitas antioksidan lebih rendah dibandingkan dengan perlakuan $\mathrm{a}_{4} \mathrm{~b}_{3}$ (perbandingan buah dan air 1:4 dan konsentrasi penstabil 1\%). Hal ini dapat terjadi karena adanya kesalahan pada saat analisis. Selain itu, diduga kondisi sampel yang sudah tidak dalam keadaan segar mempengaruhi hasil analisis.

Penilaian aktivitas antioksidan dilihat berdasarkan nilai $\mathrm{IC}_{50}$ terendah. Semakin tinggi nilai $\mathrm{IC}_{50}$, semakin rendah aktivitas antioksidan. Molyneux (2004), 
menyatakan bahwa suatu zat mempunyai sifat antioksidan bila nilai $\mathrm{IC}_{50}$ kurang dari $200 \mu \mathrm{g} / \mathrm{mL}$. Bila nilai $\mathrm{IC}_{50}$ yang diperoleh berkisar antara 200-1000 $\mu \mathrm{g} / \mathrm{mL}$, maka zat tersebut kurang aktif namun masih berpotensi sebagai zat antioksidan. Hal ini menunjukkan bahwa sari buah dengan perbandingan buah dan air 1:1 mempunyai sifat antioksidan yang kuat karena mempunyai nilai IC $_{50}$ kurang dari $200 \mu \mathrm{g} / \mathrm{mL}$.

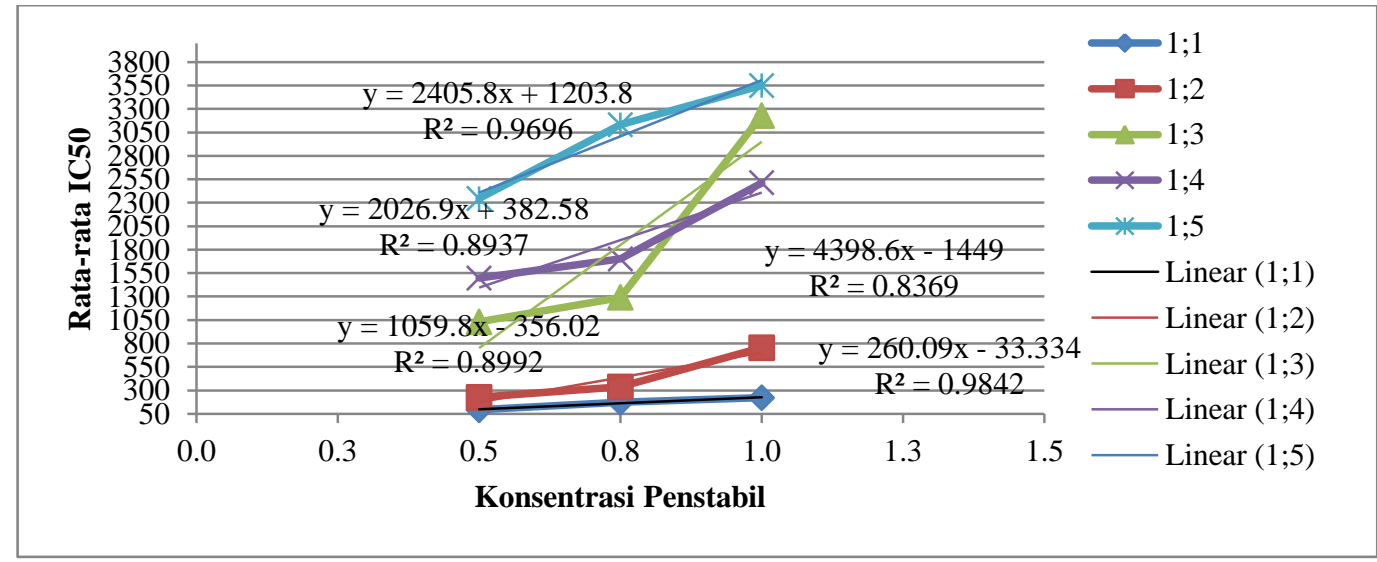

Gambar 4. Kurva Pengaruh Konsentrasi Penstabil Terhadap Aktivitas Antioksidan Sari Buah Salak Bongkok.

Penambahan konsentrasi bahan penstabil yang berbeda menunjukkan perbedaan aktivitas antioksidan dimana semakin tinggi konsentrasi penstabil yang ditambahkan, semakin rendah aktivitas antioksidan. Menurut beberpa penelitian, penambahan dekstrin dapat mempertahankan kandungan antioksdian pada bahan karena dekstrin dapat membentuk matriks yang dapat berfungsi melindungi komponen yang sensitif seperti antioksidan. Namun, hasil penelitian menunjukkan bahwa semakin tinggi konsentrasi penstabil menunjukkan penurunan aktivitas antioksidan. Hal ini dapat terjadi karena adanya proses pasteurisasi pada suhu yang cukup tinggi menyebabkan rusaknya struktur antioksidan sehingga aktivitas antioksidan pada produk menjadi rendah.

\section{Kadar Air}

Air merupakan komponen yang penting dalam bahan makanan karena air dapat mempengaruhi tekstur, penampakan dan cita rasa makanan pada umumnya. Penetapan kadar air dalam bahan makanan ini penting artinya untuk mengetahui kadar air sekaligus kadar air zat kering dalam makanan tersebut (Winarno, 1997).

Bila kandungan air relatif tinggi maka dapat diperkirakan bahan tersebut akan lebih cepat mengalami kerusakan baik oleh mikroba maupun oleh reaksi-reaksi lain. Persediaan air dalam bahan pangan maka diperkirakan akan terjadinya faktor penghambat untuk pertumbuhan mikroba. Kadar air dalam makanan perlu ditetapkan karena semakin tinggi kadar air yang terdapat dalam suatu makanan makin besar pula kemungkinan makanan tersebut cepat rusak atau tidak tahan lama (Winarno,1997).

Berdasarkan hasil analisis kadar air menunjukkan bahwa perbandingan buah dengan air (A) dan interaksinya (AB) memberikan pengaruh nyata terhadap kadar air sari buah salak Bongkok sedangkan konsentrasi penstabil (B) tidak memberikan pengaruh nyata terhadap kadar air sari buah salak Bongkok. Pengaruh interaksi perlakuan perbandingan buah dengan air dan konsentrasi penstabil terhadap kadar air sari buah salak Bongkok dapat dilihat pada Tabel 5 dan Gambar 5. 
Tabel 5. Pengaruh Interaksi Perlakuan Perbandingan Buah Dengan Air dan Konsentrasi Penstabil Terhadap Kadar Air Sari Buah Salak Bongkok.

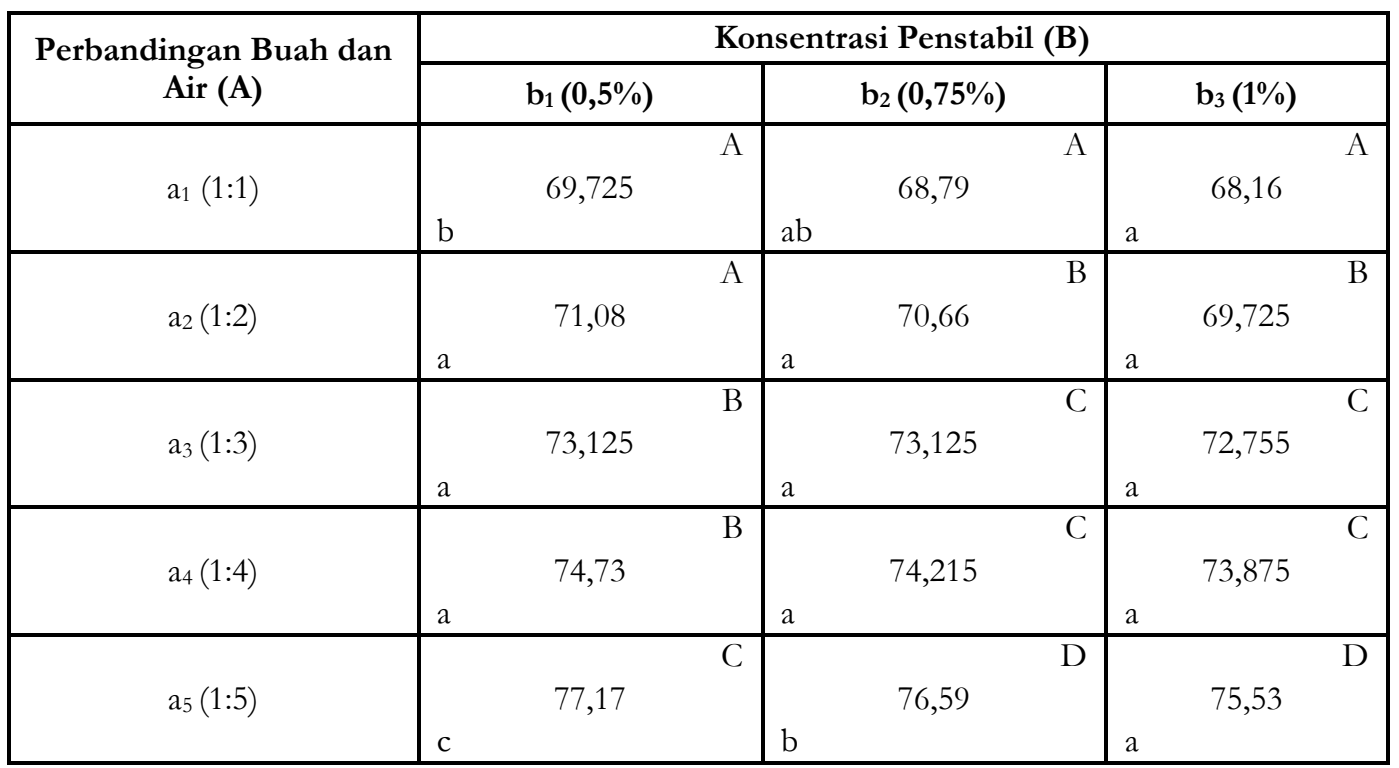

Keterangan : Setiap huruf yang berbeda menunjukkan adanya perbedaan yang nyata pada taraf 5\% Uji

Duncan (huruf kecil dibaca secara horizontal dan huruf besar secara vertikal).

Hasil uji kadar air sari buah salak Bongkok pada Tabel 5 dapat diketahui bahwa kadar air tertinggi terdapat pada perlakuan $a_{5} b_{1}$ (perbandingan buah dengan air 1:5 dan konsentrasi penstabil $0,5 \%$ ) sedangkan kadar air terendah terdapat pada perlakuan $\mathrm{a}_{1} \mathrm{~b}_{3}$ (perbandingan buah dengan air 1:1 dan konsentrasi penstabil 1\%). Tabel 9 menunjukkan bahwa semakin banyak jumlah konsentrasi penstabil yang ditambahkan, kadar air yang terkandung dalam sari buah salak semakin menurun. Hal ini dapat dihubungkan dengan total padatan terlarut dimana deksrin sebagai bahan penstabil bersifat mengikat air. Oleh karena itu, kadar air akan menurun dengan semkain banyak jumlah dekstrin yang ditambahkan.

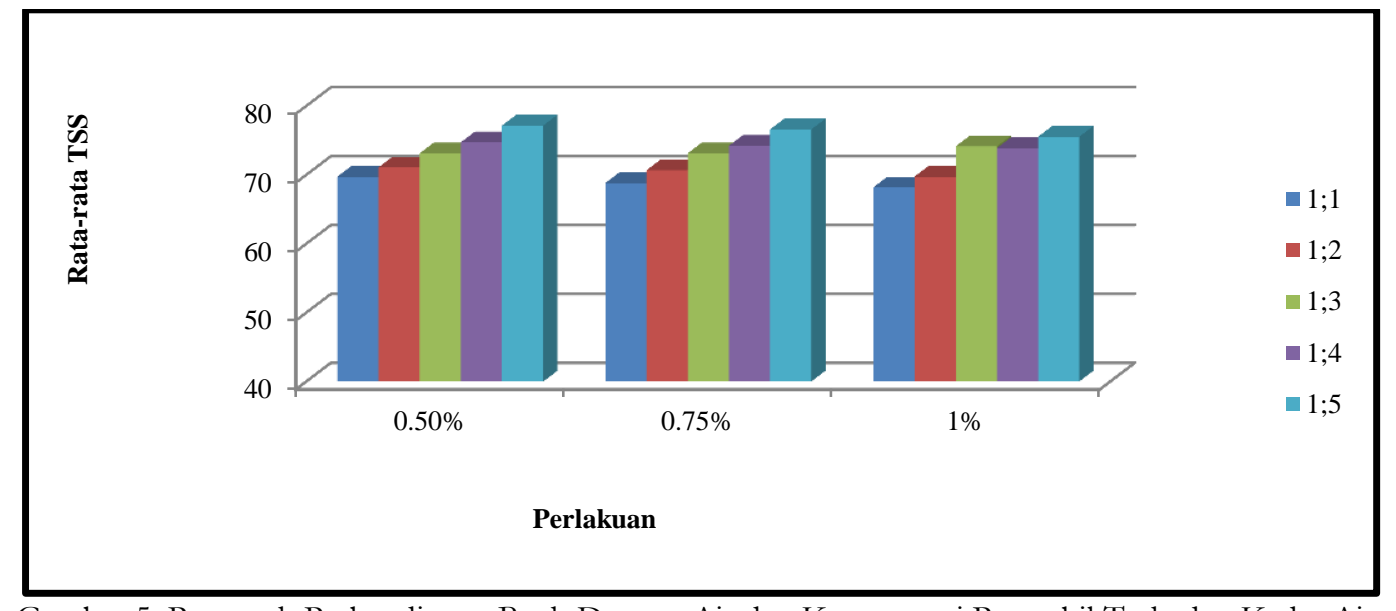

Gambar 5. Pengaruh Perbandingan Buah Dengan Air dan Konsentrasi Penstabil Terhadap Kadar Air Sari Buah Salak Bongkok. 


\section{Total Soluble Solid (TSS)}

Berdasarkan hasil analisis total soluble solid menunjukkan bahwa perbandingan buah dengan air (A) dan interaksinya $(\mathrm{AB})$ memberikan pengaruh nyata terhadap total padatan terlarut sari buah salak Bongkok sedangkan konsentrasi penstabil (B) tidak memberikan pengaruh nyata terhadap total padatan terlarut sari buah salak Bongkok. Pengaruh interaksi perlakuan perbandingan buah dengan air dan konsentrasi penstabil terhadap total soluble solid sari buah salak Bongkok dapat dilihat pada Tabel 6 dan Gambar 6.

Tabel 6. Pengaruh Interaksi Perlakuan Perbandingan Buah dengan Air dan Konsentrasi Penstabil Terhadap Total Soluble Solid Sari Buah Salak Bongkok.

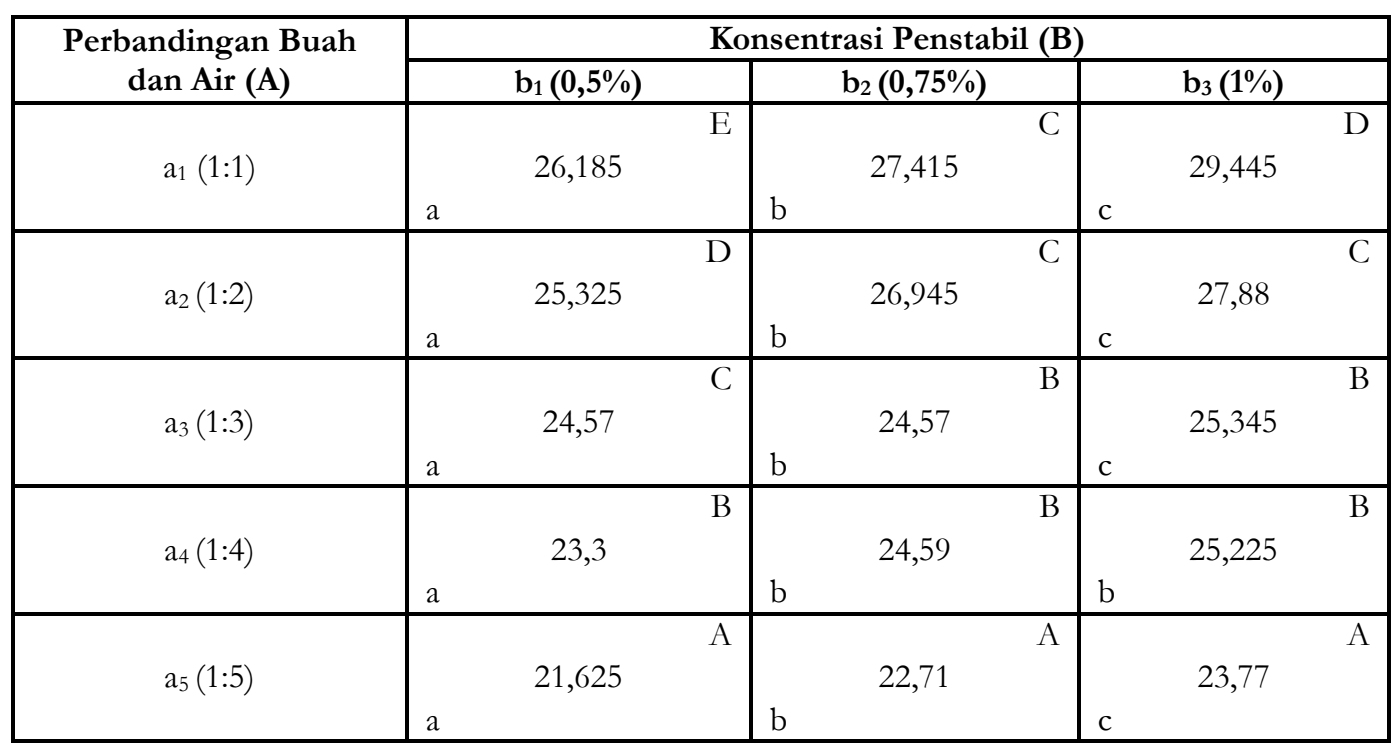

Keterangan : Setiap huruf yang berbeda menunjukkan adanya perbedaan yang nyata pada taraf 5\% Uji Duncan (huruf kecil dibaca secara horizontal dan huruf besar secara vertikal).

Tabel 6 menunjukkan bahwa total padatan terlarut tertinggi yaitu pada perlakuan $a_{1} b_{3}$ dengan total padatan terlarut sebesar 29,445\% sedangkan total padatan terlarut terendah yaitu pada perlakuan $a_{5} b_{1}$ dengan total padatan terlarut 21,625\%. Hal ini menunjukkan bahwa semakin tinggi konsentrasi penstabil yang ditambahkan maka semakin tinggi total padatan terlarut pada sampel sari buah salak Bongkok.

Total padatan terlarut meningkat karena air bebas diikat oleh bahan penstabil sehingga konsentrasi bahan yang larut meningkat. Semakin banyak partikel yang terikat bahan penstabil maka total padatan yang terlarut juga akan semakin meningkat dan mengurangi endapan yang terbentuk. Dengan adanya bahan penstabil maka partikel yang tersuspensi akan terperangkap dalam sistem tersebut dan tidak mengendap oleh pengaruh gaya gravitasi (Farikha, 2013).

Kandungan pektin dalam buah juga mempengaruhi total padatan terlarut. Pektin dalam buah akan membentuk larutan koloidal dalam air selama proses pematangan buah (Desrosier, 1988). Selama proses pematangan buah, pektin dalam buah akan terhidrolisis menjadi komponen yang larut sehingga pektin akan menurun kadarnya dan komponen yang larut dalam air akan meningkat. Total padatan terlarut akan mempengaruhi viskositas dan stabilitas sari buah. 


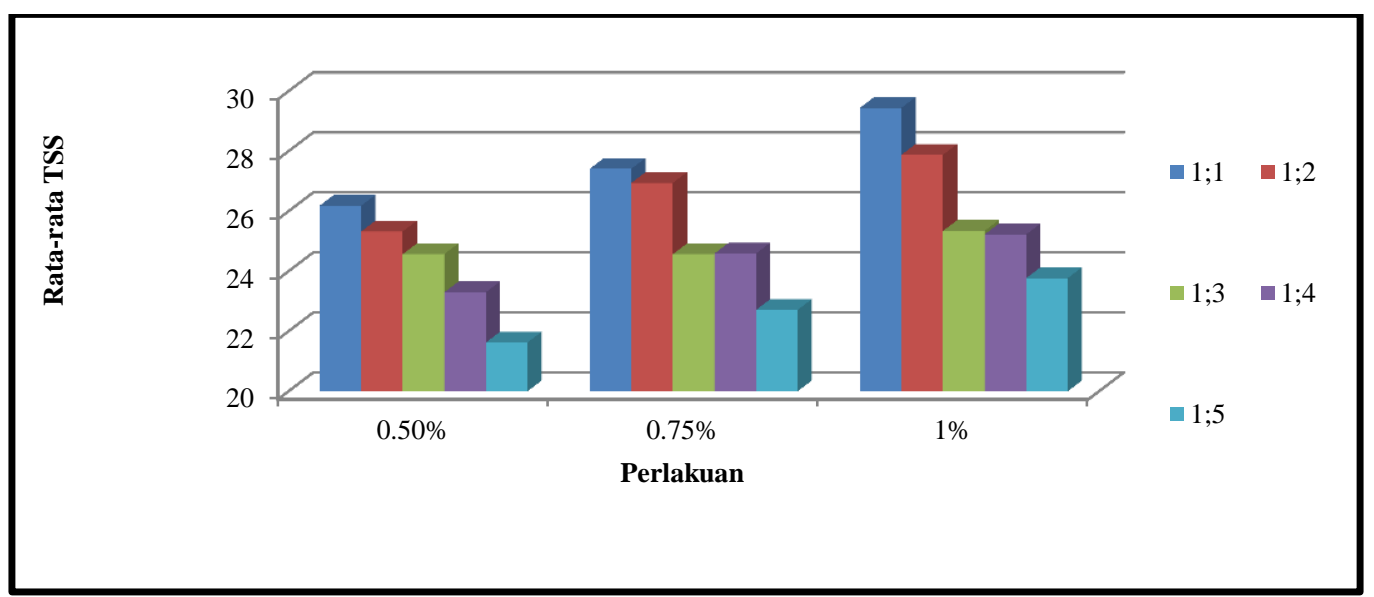

Gambar 6. Pengaruh Perbandingan Buah Dengan Air dan Konsentrasi Penstabil Terhadap Total Padatan Terlarut Sari Buah Salak Bongkok.

\section{Analisis Fisika}

Berdasarkan hasil analisis viskositas menunjukkan bahwa perbandingan buah dengan air (A) dan interaksinya (AB) memberikan pengaruh nyata terhadap viskositas sari buah salak Bongkok sedangkan konsentrasi penstabil (B) tidak memberikan pengaruh nyata terhadap viskositas sari buah salak Bongkok. Pengaruh interaksi perlakuan perbandingan buah dengan air dan konsentrasi penstabil terhadap total padatan terlarut sari buah salak Bongkok dapat dilihat pada Tabel 7 dan Gambar 7.

Tabel 7. Pengaruh interaksi perlakuan perbandingan buah dengan air dan konsentrasi penstabil terhadap viskositas sari buah salak bongkok

\begin{tabular}{|c|c|c|c|}
\hline \multirow{2}{*}{ Perbandingan Buah dan Air (A) } & \multicolumn{3}{|c|}{ Konsentrasi Penstabil (B) } \\
\hline & $b_{1}(0,5 \%)$ & $b_{2}(0,75 \%)$ & $b_{3}(1 \%)$ \\
\hline \multirow{3}{*}{$\mathrm{a}_{1}(1: 1)$} & $\mathrm{A}$ & $\mathrm{A}$ & $\mathrm{A}$ \\
\hline & 2,8885 & 3,118 & 3,3955 \\
\hline & $\mathrm{a}$ & $\mathrm{a}$ & $\mathrm{a}$ \\
\hline \multirow{3}{*}{$\mathrm{a}_{2}(1: 2)$} & A & $\mathrm{B}$ & A \\
\hline & 2,776 & 2,8015 & 2,9515 \\
\hline & $\mathrm{a}$ & $\mathrm{b}$ & $\mathrm{a}$ \\
\hline \multirow{3}{*}{$\mathrm{a}_{3}(1: 3)$} & $\mathrm{B}$ & $\mathrm{E}$ & $\mathrm{B}$ \\
\hline & 2,723 & 2,723 & 2,83 \\
\hline & $\mathrm{a}$ & $\mathrm{b}$ & $\mathrm{a}$ \\
\hline \multirow{3}{*}{$\mathrm{a}_{4}(1: 4)$} & $\mathrm{C}$ & $\mathrm{C}$ & $\mathrm{C}$ \\
\hline & 2,208 & 2,4375 & 2,636 \\
\hline & $\mathrm{a}$ & a & $\mathrm{b}$ \\
\hline \multirow{3}{*}{$a_{5}(1: 5)$} & $\mathrm{D}$ & $\mathrm{D}$ & $\mathrm{C}$ \\
\hline & 1,8705 & 2,0165 & 2,2935 \\
\hline & $\mathrm{a}$ & $\mathrm{a}$ & $\mathrm{a}$ \\
\hline
\end{tabular}

Keterangan : Setiap huruf yang berbeda menunjukkan adanya perbedaan yang nyata pada taraf $5 \%$

Uji Duncan (huruf kecil dibaca secara horizontal dan huruf besar secara vertikal).

Hasil uji viskositas sari buah salak Bongkok pada tabel 10 dapat diketahui bahwa semakin sedikit jumlah penambahan air dan semakin tinggi penambahan konsentrasi bahan penstabil menghasilkan nilai viskositas yang tinggi. Viskositas tertinggi terjadi pada perlakuan $a_{1} b_{3}$ (perbandingan buah dengan air 1:3 dan konsentrasi penstabil 1\%) sedangkan viskositas terendah terdapat pada 
perlakuan as $b_{1}$ (perbandingan buah dengan air 1:1 dan konsentrasi penstabil $0,5 \%)$. Hal ini didukung oleh Belizt (2009), yang menyatakan bahwa viskositas dipengaruhi oleh konsentrasi dan bobot penstabil. Semakin tinggi nilai bobot penstabil yang diberikan maka viskositas produk akan meningkat.

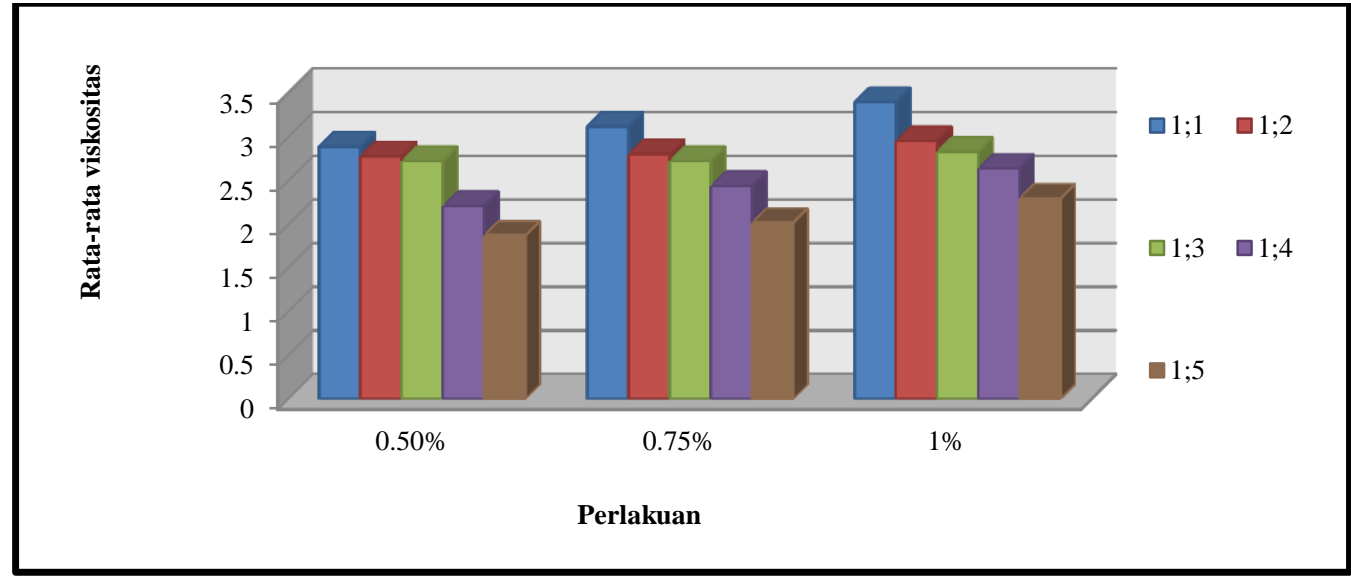

Gambar 7. Pengaruh Perbandingan Buah Dengan Air dan Konsentrasi Penstabil Terhadap Viskositas Sari Buah Salak Bongkok

\begin{abstract}
Adanya proses pasteurisasi selama pengolahan menyebabkan terbentuknya gel oleh pektin sehingga viskositasnya meningkat. Pektin membentuk gel pada kondisi kandungan gula yang tinggi dan nilai $\mathrm{pH}$ yang rendah (asam) pada suhu $60-90^{\circ} \mathrm{C}$. Kisaran tingkat keasaman pektin adalah 1,2-3,0. Jika $\mathrm{pH}$ terlalu tinggi maka pektin akan berubah menjadi asam pektat, sehingga tidak dapat membentuk gel (Manalo, et. al, 1985).
\end{abstract}

\section{Analisis Organoleptik \\ Rasa}

Rasa merupakan faktor penting dalam mengambil keputusan terakhir konsumen untuk menerima atau menolak dari suatu produk makanan. Rasa suatu bahan pangan merupakan hasil kerjasama indera-indera yang lain seperti penglihatan, penciuman, pendengaran dan peraba ikut berperan dalam pengamatan bahan pangan. Pada umumnya bahan pangan tidak hanya terdiri dari salah satu rasa saja, akan tetapi merupakan gabungan dari berbagai macam rasa yang terpadu sehingga akan menimbulkan cita rasa makanan yang utuh dan padu (Kartika dkk, 1987).

Berdasarkan hasil uji organoleptik terhadap rasa sari buah salak Bongkok menunjukkan bahwa konsentrasi penstabil (B) tidak memberikan pengaruh nyata, sedangkan perbandingan buah salak dengan air (A) dan interaksinya (AB) berpengaruh terhadap rasa sari buah salak Bongkok. Pengaruh interaksi perlakuan perbandingan buah dengan air dan konsentrasi penstabil terhadap rasa sari buah salak Bongkok dapat dilihat pada Tabel 8 dan Gambar 8. 
Tabel 8. Pengaruh Interaksi Perlakuan Perbandingan Buah dengan Air dan Konsentrasi Penstabil Terhadap Rasa Sari Buah Salak Bongkok.

\begin{tabular}{|c|c|c|c|}
\hline \multirow{2}{*}{ Perbandingan Buah dan Air (A) } & \multicolumn{3}{|c|}{ Konsentrasi Penstabil (B) } \\
\hline & $b_{1}(0,5 \%)$ & $b_{2}(0,75 \%)$ & $b_{3}(1 \%)$ \\
\hline$a_{1}(1: 1)$ & $\begin{array}{c}5,05 \mathrm{C} \\
\mathrm{a}\end{array}$ & $\begin{array}{c}4,725 \mathrm{D} \\
\mathrm{a}\end{array}$ & $\begin{array}{c}4,575 \mathrm{D} \\
\mathrm{a}\end{array}$ \\
\hline$a_{2}(1: 2)$ & $\begin{array}{c}4,575 \text { B } \\
\text { a }\end{array}$ & $\begin{array}{c}4,25 \mathrm{D} \\
\mathrm{a}\end{array}$ & $\begin{array}{c}4,25 \mathrm{C} \\
\mathrm{a}\end{array}$ \\
\hline$a_{3}(1: 3)$ & $\begin{array}{c}4,225 \mathrm{~B} \\
\mathrm{~b}\end{array}$ & $\begin{array}{c}3,45 \mathrm{C} \\
\mathrm{a}\end{array}$ & $\begin{array}{c}4,075 \mathrm{C} \\
\mathrm{b}\end{array}$ \\
\hline$a_{4}(1: 4)$ & $\begin{array}{c}2,75 \text { A } \\
\mathrm{a}\end{array}$ & $\begin{array}{c}3,275 \text { B } \\
\text { b }\end{array}$ & $\begin{array}{c}3,475 \text { B } \\
\text { b }\end{array}$ \\
\hline$a_{5}(1: 5)$ & $\begin{array}{c}2,65 \mathrm{~A} \\
\mathrm{a}\end{array}$ & $\begin{array}{c}2,825 \mathrm{~A} \\
\mathrm{a}\end{array}$ & $\begin{array}{c}2,6 \text { A } \\
a\end{array}$ \\
\hline
\end{tabular}

Keterangan : Setiap huruf yang berbeda menunjukkan adanya perbedaan yang nyata pada taraf 5\% Uji Duncan (huruf kecil dibaca secara horizontal dan huruf besar secara vertikal).

Tabel 8 menunjukkan bahwa semakin banyak penambahan air, penilaian panelis terhadap sari buah salak Bongkok semakin rendah. Pada Tabel 12 dapat dilihat pada interaksi perlakuan $\mathrm{a}_{1} \mathrm{~b}_{1}$ yaitu perbandingan buah dengan air 1:1 dan konsentrasi dekstrin $0,5 \%$ memiliki rasa yang paling disukai panelis dengan nilai rata-rata 5,05 sedangkan interaksi perlakuan $a_{5} b_{3}$ yaitu perbandingan buah dengan air 1:5 dan konsentrasi dekstrin $1 \%$ menunjukkan hasil penilaian paling rendah dengan nilai rata-rata 2,6. Hal ini dapat disebabkan karena pada perlakuan $a_{1} b_{1}$ jumlah air yang ditambahkan sama dengan jumlah buah salak sehingga menghasilkan sari buah yang memiliki rasa khas buah salak yang lebih kuat dibandingkan dengan perlakuan lain yang memiliki perbandingan air yang lebih banyak sehingga menghasilkan rasa sari buah salak yang kurang memiliki rasa khas buah salak.

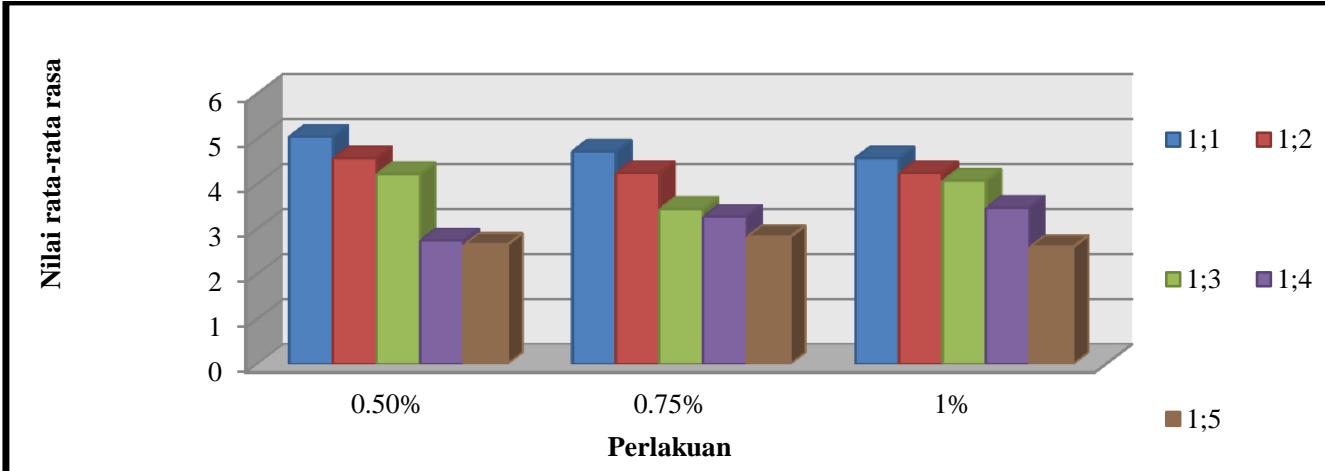

Gambar 8. Pengaruh perbandingan buah dengan air (a) dan konsentrasi penstabil (b) terhadap rasa sari buah salak bongkok.

\section{Aroma}

Aroma merupakan salah satu faktor penting bagi konsumen dalam memilih produk pangan yang paling disukai. Aroma bahan makanan merupakan suatu komponen tertentu yang mempunyai beberapa fungsi dalam makanan, yaitu bersifat memperbaiki dan membuat lebih dapat diterima (Winarno, 1997). 
Aroma suatu produk makanan atau minuman berperan penting dalam penilaian suatu produk. Aroma khas yang timbul dapat dirasakan oleh indera penciuman tergantung pada bahan pangan penyusunnya, misalnya faktor pengolahan yang berbeda, maka aroma yang ditimbulkan akan berbeda pula.

Berdasarkan hasil uji organoleptik menunjukkan bahwa konsentrasi penstabil (B) tidak memberikan pengaruh terhadap aroma, sedangkan perbandingan buah salak dengan air (A) dan interaksinya (AB) berpengaruh terhadap aroma sari buah salak Bongkok. Pengaruh interaksi perlakuan perbandingan buah dengan air dan konsentrasi penstabil terhadap aroma sari buah salak Bongkok dapat dilihat pada Tabel 9 dan Gambar 9.

Tabel 9. Pengaruh Interaksi Perlakuan Perbandingan Buah dengan Air dan Konsentrasi Penstabil Terhadap Aroma Sari Buah Salak Bongkok.

\begin{tabular}{|c|c|c|c|}
\hline \multirow{2}{*}{$\begin{array}{c}\text { Perbandingan } \\
\text { Buah dan Air } \\
\text { (A) }\end{array}$} & $\mathbf{b}_{\mathbf{1}} \mathbf{( 0 , 5 \% )}$ & $\mathbf{b}_{\mathbf{2}} \mathbf{( 0 , 7 5 \% )}$ & $\mathbf{b}_{\mathbf{3}} \mathbf{( 1 \%} \mathbf{)}$ \\
\cline { 2 - 4 } & $4,375 \mathrm{~B}$ & $4,4 \mathrm{~B}$ & $4,45 \mathrm{~B}$ \\
$\mathrm{a}_{1}(1: 1)$ & $\mathrm{a}$ & $\mathrm{a}$ & $\mathrm{a}$ \\
\hline \multirow{2}{*}{$\mathrm{a}_{2}(1: 2)$} & $4,175 \mathrm{~B}$ & $4,075 \mathrm{~A}$ & $4,075 \mathrm{~A}$ \\
& $\mathrm{a}$ & $\mathrm{a}$ & $\mathrm{a}$ \\
\hline \multirow{2}{*}{$\mathrm{a}_{3}(1: 3)$} & $4,25 \mathrm{~B}$ & $3,875 \mathrm{~A}$ & $4,075 \mathrm{~A}$ \\
& $\mathrm{~b}$ & $\mathrm{a}$ & $\mathrm{b}$ \\
\hline \multirow{2}{*}{$\mathrm{a}_{4}(1: 4)$} & $3,925 \mathrm{~A}$ & $\mathrm{~A}$ & $4,125 \mathrm{~A}$ \\
& $\mathrm{a}$ & $3,975 \mathrm{~A}$ & $\mathrm{a}$ \\
\hline \multirow{2}{*}{$\mathrm{a}_{5}(1: 5)$} & $3,875 \mathrm{~A}$ & $\mathrm{a}$ & $3,975 \mathrm{~A}$ \\
& $\mathrm{a}$ & $\mathrm{a}$ & $\mathrm{a}$ \\
\hline
\end{tabular}

Keterangan : Setiap huruf yang berbeda menunjukkan adanya perbedaan yang nyata pada taraf 5\%

Uji Duncan (huruf kecil dibaca secara horizontal dan huruf besar secara vertikal).

Tabel 9 menunjukkan bahwa interaksi perlakuan $\mathrm{a}_{1} \mathrm{~b}_{3}$ yaitu perbandingan buah dengan air 1:1 dan konsentrasi dekstrin 1\% memiliki aroma yang paling disukai panelis dengan nilai rata-rata 4,45. Penilaian panelis terhadap aroma sama halnya dengan penilaian panelis terhadap rasa dimana semakin banyak jumlah air yang ditambahkan maka penilaian panelis semakin rendah karena semakin banyak penambahan air maka aroma khas buah salak sudah berkurang.

Hasil penilaian panelis terhadap perlakuan $a_{3} b_{2}$ (perbandingan buah dengan air 1:3 dan konsentrasi penstabil $0,75 \%$ memiliki nilai rata-rata lebih rendah dibandingkan dengan perlakuan $\mathrm{a}_{4} \mathrm{~b}_{2}$ (perbandingan buah dengan air 1:4 dan konsentrasi penstabil 0,75\%) dan $\mathrm{a}_{5} \mathrm{~b}_{2}$ (perbandingan buah dengan air 1:5 dan konsentrasi penstabil 0,75\%). Selain itu, pada perlakuan $a_{3} b_{3}$ (perbandingan buah dengan air 1:3 dan konsentrasi penstabil 1\%) juga mempunyai nilai ratarata yang lebih rendah dibandingkan dengan perlakuan $a_{4} b_{3}$ (perbandingan buah dengan air 1:4 dan konsentrasi penstabil 1\%). Hal ini dapat disebabkan karena adanya faktor-faktor yang mempengaruhi penilaian panelis seperti adanya aroma lain di sekitar tempat pengujian sehingga mempengaruhi indera penciuman panelis. Selain itu, kesalahan penilaian juga dapat disebabkan karena perbedaan sensitvitas indera penciuman panelis berbeda-beda dan faktor-faktor lain yang mendukung terjadinya kesalahan dalam pengujian.

Aroma yang khas dan biasa dirasakan oleh indera pencium tergantung kepada bahan penyusunnya dan bahan yang ditambahkan pada makanan tersebut. Sedangkan penilaian terhadap aroma dipengaruhi oleh faktor psikis dan fisiologi yang memberikan pendapat berlainan (Kartika dkk., 1988). 


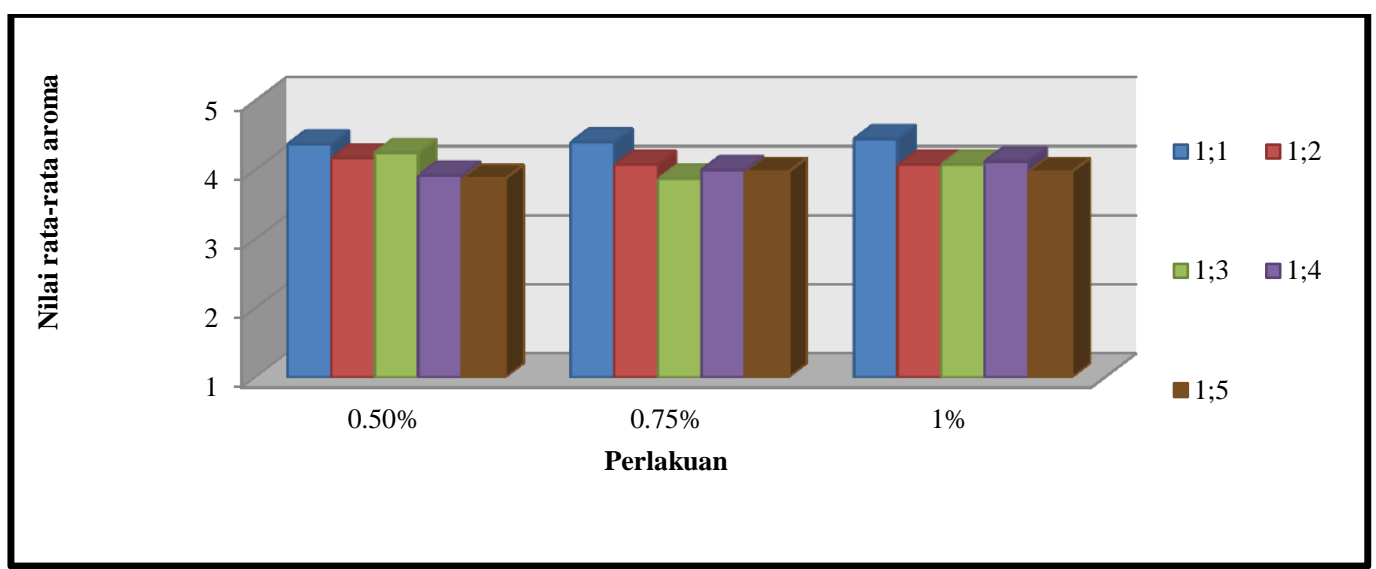

Gambar 9. Pengaruh perbandingan buah dengan air (a) dan konsentrasi penstabil (b) terhadap aroma sari buah salak bongkok.

\section{Kenampakan}

Berdasarkan hasil uji organoleptik menunjukkan bahwa konsentrasi penstabil (B) tidak memberikan pengaruh terhadap kenampakan sari buah salak, sedangkan perbandingan buah salak dengan air (A) dan interaksinya (AB) berpengaruh terhadap kenampakan sari buah salak Bongkok. Pengaruh interaksi perlakuan perbandingan buah dengan air dan konsentrasi penstabil terhadap kenampakan sari buah salak Bongkok dapat dilihat pada Tabel 10.

Tabel 10. Pengaruh Interaksi Perlakuan Perbandingan Buah dengan Air dan Konsentrasi Penstabil Terhadap Kenampakan Sari Buah Salak Bongkok.

\begin{tabular}{|c|c|c|c|}
\hline \multirow{2}{*}{ Perbandingan Buah dan Air (A) } & \multicolumn{3}{|c|}{ Konsentrasi Penstabil } \\
& \multicolumn{3}{|c|}{$(\mathbf{B})$} \\
\cline { 2 - 4 } & $\mathbf{b}_{\mathbf{1}} \mathbf{( 0 , 5 \% )}$ & $\mathbf{b}_{\mathbf{2}} \mathbf{( 0 , 7 5 \% )}$ & $\mathbf{b}_{\mathbf{3}} \mathbf{( 1 \%} \mathbf{)}$ \\
\hline \multirow{2}{*}{$\mathrm{a}_{1}(1: 1)$} & $4,525 \mathrm{C}$ & $4,175 \mathrm{~B}$ & $4,075 \mathrm{~A}$ \\
& $\mathrm{~b}$ & $\mathrm{a}$ & $\mathrm{a}$ \\
\hline \multirow{2}{*}{$\mathrm{a}_{2}(1: 2)$} & $4,2 \mathrm{~B}$ & $4,125 \mathrm{~B}$ & $4,1 \mathrm{AB}$ \\
& $\mathrm{a}$ & $\mathrm{a}$ & $\mathrm{a}$ \\
\hline \multirow{2}{*}{$\mathrm{a}_{3}(1: 3)$} & $4,275 \mathrm{~B}$ & $3,2 \mathrm{~A}$ & $4,025 \mathrm{~A}$ \\
& $\mathrm{~b}$ & $\mathrm{a}$ & $\mathrm{b}$ \\
\hline \multirow{2}{*}{$\mathrm{a}_{4}(1: 4)$} & $4,125 \mathrm{~B}$ & $3,75 \mathrm{~A}$ & $3,625 \mathrm{~A}$ \\
& $\mathrm{a}$ & $\mathrm{a}$ & $\mathrm{a}$ \\
\hline \multirow{2}{*}{$\mathrm{a}_{5}(1: 5)$} & $2,875 \mathrm{~A}$ & $3,225 \mathrm{~B}$ & $3,575 \mathrm{~A}$ \\
& $\mathrm{a}$ & $\mathrm{ab}$ & $\mathrm{a}$ \\
\hline
\end{tabular}

Keterangan : Setiap huruf yang berbeda menunjukkan adanya perbedaan yang nyata pada taraf 5\% Uji Duncan (huruf kecil dibaca secara horizontal dan huruf besar secara vertikal).

Tabel 10 menunjukkan bahwa interaksi perlakuan $\mathrm{a}_{1} \mathrm{~b}_{1}$ yaitu perbandingan buah dengan air 1:1 dan konsentrasi dekstrin 0,5\% memiliki kenampakan yang paling disukai panelis dengan nilai rata-rata 4,525 sedangkan interaksi perlakuan $\mathrm{a}_{5} \mathrm{~b}_{1}$ mempunyai nilai rata-rata terendah yaitu 2,875 .

Penilaian atribut kenampakan sari buah Salak dalam hal ini adalah penilaian terhadap terbentuknya endapan pada sari buah salak. Kesalahan panelis dalam memberikan penilaian dapat terjadi karena beberapa faktor, salah satunya oleh warna dari produk. Sampel dengan perlakuan penambahan air yang lebih sedikit menghasilkan warna produk yang lebih pekat sehingga endapan yang terbentuk kurang terlihat sedangkan sampel dengan perlakuan penambahan air yang lebih banyak menghasilkan warna produk yang kurang pekat 
sehingga endapat yang terbentuk dapat terlihat dengan jelas. Selain itu, faktorfaktor lain dapat mempengaruhi penilaian panelis terhadap sampel seperti adanya pengaruh dari panelis lain. Pengaruh perbandingan buah dengan air dan konsentrasi penstabil terhadap aroma sari buah salak dapat dilihat pada Gambar 10.

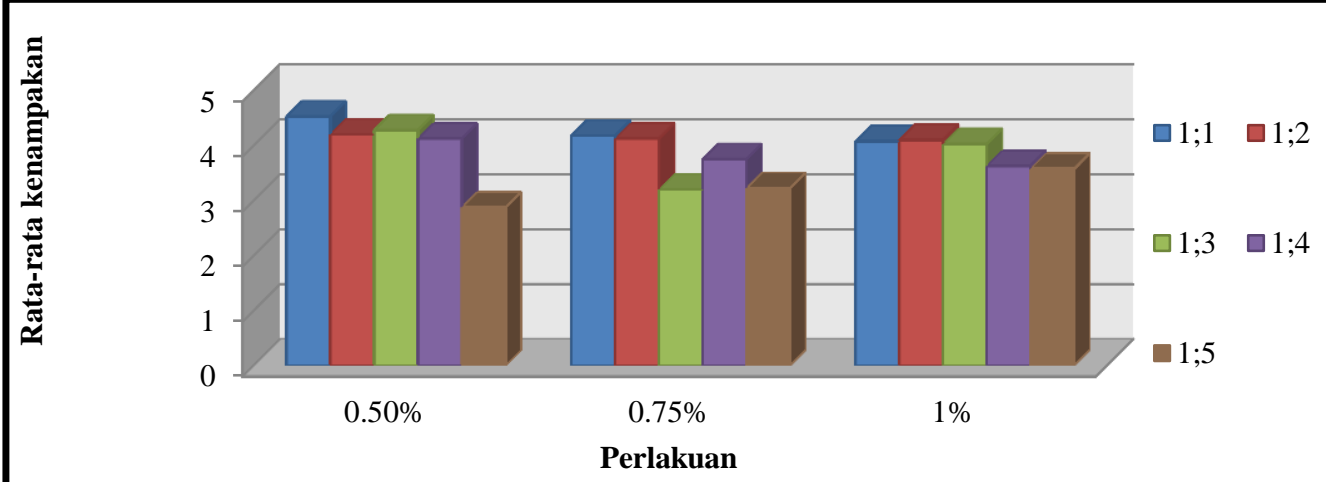

Gambar 10. Pengaruh Perbandingan Buah dengan Air (A) dan Konsentrasi Penstabil (B) Terhadap Kenampakan Sari Buah Salak Bongkok.

\section{Produk Terpilih}

Berdasarkan hasil analisis kimia, fisika dan pengujian organoleptik sari buah salak Bongkok pada penelitian utama maka diperoleh sampel terbaik yaitu sari buah salak Bongkok dengan perlakuan $a_{1} b_{1}$ (perbandingan buah dan air 1:1 dan konsentrasi penstabil 0,5\%). Pemilihan produk terpilih ini ditentukan berdasarkan penilaian organoleptik terhadap rasa yang mempunyai penilaian tertinggi. Selain itu pemilihan produk terpilih ini berdasarkan aktivitas antioksidan tertinggi dari sampel. Produk sari buah Salak Bongkok dengan perlakuan $a_{1} b_{1}$ (perbandingan buah dan air 1:1 dan konsentrasi penstabil 0,5\%) memiliki aktivitas antioksidan sebesar 91,9555 $\mu \mathrm{g} / \mathrm{mL}$, kadar air 72,5\%, TSS sebesar 26,185\% dan viskositas sebesar $2,8885 \mathrm{~kg} / \mathrm{m} . \mathrm{s}$

\section{KESIMPULAN DAN SARAN}

\section{Kesimpulan}

1. Berdasarkan hasil uji organoleptik pada penelitian pendahuluan terhadap rasa, aroma dan kenampakan sari buah salak Bongkok, didapat hasil perlakuan terbaik yaitu pada sampel dengan perlakuan penambahan sukrosa sebesar $10 \%$ dan jenis penstabil dekstrin.

2. Berdasarkan respon kimia, respon fisik dan respon organoleptik pada penelitian utama didapatkan hasil bahwa perlakuan variasi perbandingan buah dengan air dan konsentrasi penstabil berpengaruh terhadap karakteristik sari buah salak Bongkok.

3. Berdasarkan hasil analisis kimia, fisika dan uji organoleptik sari buah salak Bongkok didapat sampel terpilih yaitu pada perlakuan $a_{1} b_{1}$ (perbandingan buah dan air 1:1 dan konsentrasi penstabil 0,5\%) yang memiliki aktivitas antioksidan sebesar 91,9555 $\mu \mathrm{g} / \mathrm{mL}$, kadar air $69,725 \%$, TSS sebesar $26,185 \%$ dan viskositas sebesar $2,8885 \mathrm{~kg} / \mathrm{m}$.s.

\section{Saran}

Berdasarkan penelitian, maka saran -saran yang dapat diberikan adalah sebagai berikut:

1. Perlu dilakukan penelitian lanjutan untuk mengetahui umur simpan produk sari buah salak Bongkok. 
2. Sebaiknya dilakukan pengujian ulang terhadap analisis antioksidan dengan sampel yang dievaporasi terlebih dahulu.

3. Perlu dilakukan penelitian lanjutan mengenai variasi proses blanching untuk mendapatkan warna sari buah yang lebih menarik.

\section{DAFTAR PUSTAKA}

Afrianti, L. H., E. Y. Sukandar, S. Ibrahim, I. K. Adnyana. 2007. Xanthine Oxidase inbibitor activity of terpenoid and pyrrole compounds isolated from snake fruit (Salacca edulis Reinw) Cv. Bongkok. Journal Applied Science. 7(20):31273130ISSN : 1812-5654.

Afrianti, L. H., E. Y. Sukandar, S. Ibrahim, I. K. Adnyana. 2010. Senyawa Asam 2- Metilester-1H-Pirol-4-Karboksilat dalam Ekstrak Etil Asetat Buah Salak Varietas Bongkok sebagai Antioksidan dan Antibyperuricemia. Jurnal Teknologi dan Industri Pangan, Vol. XXI No.1. Hal 66-72.

Afrianti, L. H., E. Y. Sukandar, S. Ibrahim, I. K. Adnyana. 2011. Aktivitas Antihiperurikemia Ekstrak Etil Asetat dan Etanol Buah Salak Varietas Bongkok (Salacca edulis Reinw.) Pada Tikus Galur Wistar. Jurnal Teknologi dan Industri Pangan, Vol. XXII, No.1. Hal 7-10.

Amalia, Z. 2011. Formulasi Penggunaan Dekstrin, Carboxymethylcellulose (CMC) dan Madu pada Pembuatan Sirup Buah Kawis (Limonia acidissima) Alami. Skripsi Universitas Negeri Semarang. (Salacca edulis Reinw) Cv. Bongkok, J of Applied Sciences 7(20): 3127-3130. ISSN : 1812 5654 .

Amin, I., Lee, W. Y. 2005. Effect of Different Blanching Times on Antioxidant Properties in Selected
Cruciferous Vegetables. Journal of the Science of Food and Agriculture 85 (13): 2314-2320.

Aminah, S., Tezar, R., A. Bain. 2008. Optimasi Pemanfaatan Stevia sebagai Pemanis Alami Pada Sari Buah Belimbing Manis. Jurnal Agriplus, Volume 18 Nomor : 03.

Anonimus. 1992. Dekstrin Industri Pangan. Badan Standardisasi Nasional.

Anonimus. 1995. Minuman Sari Buah. Badan Stanarisasi Nasional.

Anonimus. 2002, Laporan Tahunan Kabupaten Sumedang, Dinas Pertanian Kabupaten Sumedang Jawa Barat.

Anonimus. 2012, Badan Pusat Statistik Jawa Barat.

Apriyantono, A., D. Fardiaz, N. L. Puspitasari, Sedamawati dan S. Budiyanto. 1989. Analisis Pangan. PAU Pangan dan Gizi. IPB Press.

Ariyanto, D. H., F. Hidayatulloh, J. Murwono. 2013. Pengaruh Penambahan Gula Terhadap Produktivitas Alkohol Dalam Pembuatn Wine Berbahan Apel Buang (Reject) dengan Menggunakan Nopkor MZ.11. Jurnal Teknologi Kimia dan Industri, Vol. 2 No. 4.

Association of Official Analytical Chemists (AOAC). 1995. Official Methods of Analysis of AOAC International. Maryland.

Belitz, H. D. W. 2009. Food Chemistry 4th revised and extended Edition.. Springer Verlag Berlin Heidelberg, New York.

Desroiser, N. W. 1988. Teknologi Pengawetan Pangan, Edisi Ketiga. Universitas Indonesia, Jakarta

Farikha, I. N., C. Anam, E. Widowati. 2013. Pengaruh Jenis dan Konsentrasi Bahan Penstabil Alami Terhadap Karakteristik Fisikokimia Sari Buah Naga 
Merah (Hylocereus Polyrhizus) Selama Penyimpanan. Jurnal Teknosains Pangan Vol 2 No 1.

Fauzan, A. 2010. Pengaruh Penambahan Na-CMC Dan Gula Pasir Terhadap Kualitas Sari Buah Nangka (Jackfruit). Jurnal Ilmiah PertanianVol. 13 No. 9.

Gitawuri G, Purwadi, D. Rosyidi. 2014. Penambahan Gum Arab Pada Minuman Madu Sari Buah Jambu Merah Ditijau dari $\mathrm{pH}$, Viskositas, TPC dan Mutu Organoleptik. Jurnal Fakultas Peternakan, Universitas Brawijaya, Malang.

Gustianova H. 2012. Perbandingan Ekstrak Salak Dengan Air Terhadap Karakteristik Minuman Ekstrak Buah Salak Bongkok (Salacca Edulis Reinw). Skripsi Universitas Pasundan, Bandung.

Josephy, P. D. 1997. Molecular Toxicology Oxford University Press, New York

Kamal, N. 2010. Pengaruh Bahan Aditif CMC (Carboxyl Metbyl Cellulose) Terhadap Beberapa Parameter Pada Larutan Sukrosa. Jurnal Teknologi Vol. 1 Edisi 17.

Kartika, B., Hastuti, P., dan Supartono, W. 1987 Pedoman Uji Inderawi Bahan Pangan, Edisi I. Pusat Antar Universitas Pangan dan Gizi Yogyakarta.

Manalo, J. B., K. C. Torres and F. E. Anzaldo. 1985. Pektin and Product of Kalamansi (Citrus microcarpa Bunge) Fruits Waste. NIST Journal.

Manoi, F. 2006. Pengaruh Konsentrasi Karboksil Metil Selulosa (CMC) Terhadap Mutu Sirup Jambu Mete (Anacardium occidentale L.). Balai Penelitian Tanaman Obat dan Aromatik.

Molyneux, P. 2004. The Use Of The Stable Free Radical Diphenylpicrylbydrazyl (DPPH) For Estimating Antioxidant Activity.J. Sci.
Technology.

Permatasari, D. 2012. Pengaruh Konsentrasi Sukrosa Dan Lama Perendaman Dalam Larutan Kapur $\quad \mathrm{Ca}(\mathrm{OH})_{2} \quad$ Terhadap Karakteristik Kurma Salak Varietas Bongkok (Salacca Edulis Reinw). Universitas Pasundan, Bandung.

Pertiwi, M. F. D. dan W. H. Susanto. 2014. Pengaruh Proporsi (Buah : Sukrosa) dan Lama Osmosis Terhadap Kualitas Sari Buah Stroberi (Fragaria vesca L). Jurnal Pangan dan Agroindustri Vol. 2 No. 2.

Prasetyo, B. B., Purwadi, D. Rosyidi. 2014. Penambahan CMC (Carboxy Methyl Cellulose) Pada Pembuatan Minuman Madu Sari Buah Jambu Merah (Psidium guajava) ditinjau dari $\mathrm{pH}$, Viskositas, Total Kapang dan Mutu Organoleptik. Jurnal Fakultas Peternakan, Universitas Brawijaya, Malang.

Rukmana, R. 1999. Salak Prospek Agribisnis dan Teknik Usaha Tani. Penerbit Kanisius. Jakarta.

Sa'adah, L. I. N., T. Estiasih. 2015. Karakterisasi Minuman Sari Apel Produksi Skala Mikro dan Kecil Di Kota Batu: Kajian Pustaka. Jurnal Pangan dan Agroindustri Vol. 3 No 2 p.374-380.

Saptoningsih, A. Jatnika. 2012. Membuat Olahan Buah. Penerbit PT AgroMedia Pustaka, Jakarta.

Siskawardani, D. D., N. Komar, M. B. Hermanto. 2013. Pengaruh Konsentrasi Na-CMC (NatriumCarboxymethyle Cellulose) dan Lama Sentrifugasi terhadap Sifat Fisik Kimia Minuman Asam Sari Tebu (Saccharum officinarum L). Jurnal Bioproses Komoditas Tropis Vol. 1 No. 1.

Sudarmadji, S. 1976. Analisis Bahan Makanan dan Pertanian, Edisi I. Penerbit Liberty, Yogyakarta.Suhartini, E. 2002. 
Pengaruh Konsentrasi CMC dan Sukrosa Terhadap Jus Lidah Buaya (Aloe vera). Jurusan Teknologi Pangan, Fakultas Teknik, Universitas Pasundan, Bandung.

Suter, I. K. 1988. Telaah Sifat Buah Salak di Bali sebagai Dasar Pembinaan Mutu Hasil. Tesis. Institut Pertanian Bogor. Bogor.56-63.

Tranggono, S., Haryadi, Suparmo, A. Murdiati, S. Sudarmadji, K. Rahayu, S. Naruki, dan M. Astuti. 1991. Bahan Tambahan Makanan (Food Additive). PAU Pangan dan Gizi UGM, Yogyakarta.

Triyono A. 2010. Pengaruh Konsentrasi Ragi Terhadap Karakteristik Sari Buah dari Beberapa Varietas Pisang (Musaparadisiaca L). Prosiding Seminar Nasional Teknik Kimia "Kejuangan”, Yogyakarta.

Widyasari, Rucita, 2007. Aplikasi Penambahan Flokulan terhadap Pengolahan Sari Buah Jambu Mete. Skripsi, Institut Pertanian Bogor, Bogor.

Winarno, F. G. 1997. Kimia Pangan dan Gizi. Penerbit Gramedia Pustaka Utama, Jakarta. 